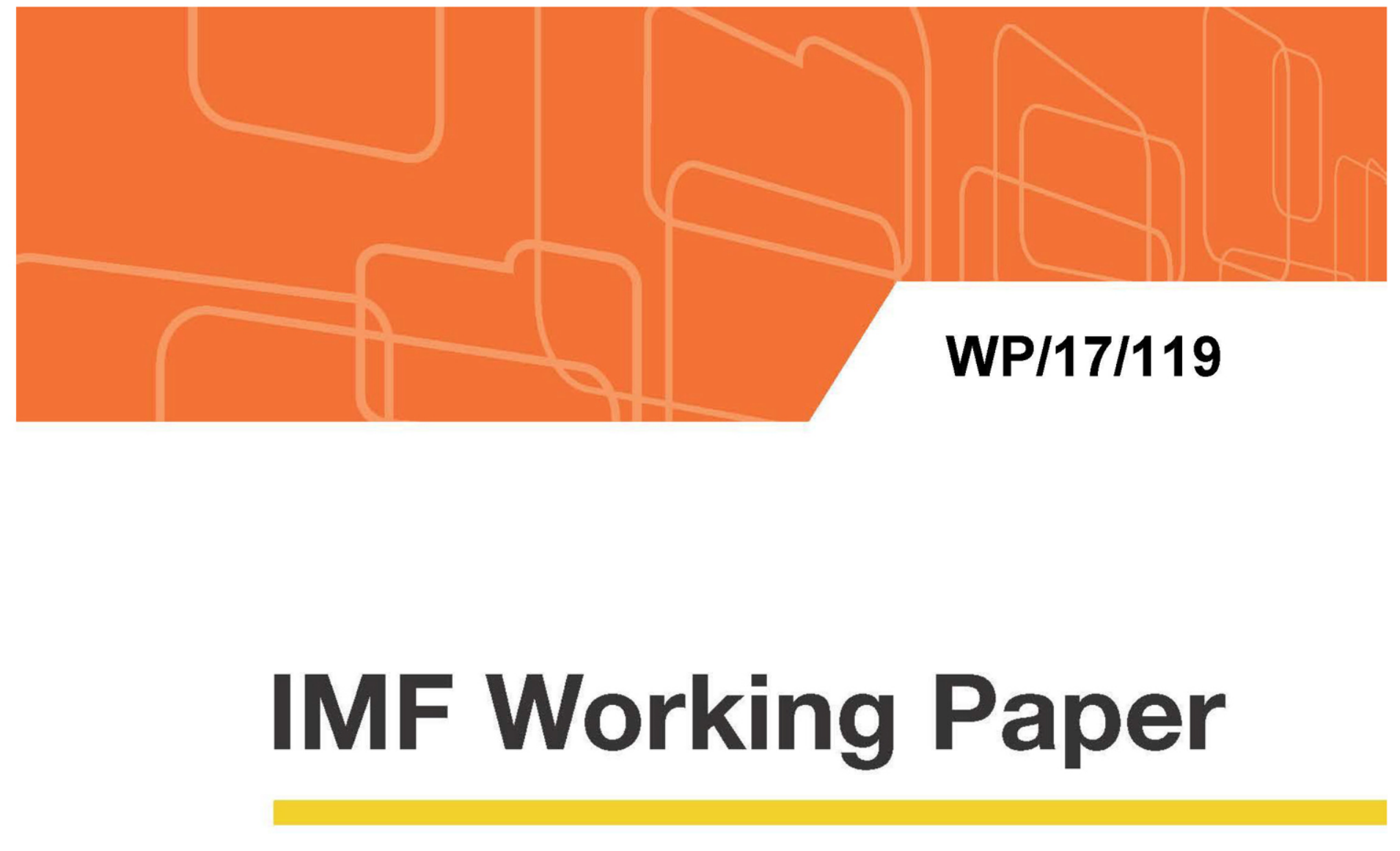

\title{
Sovereign Bond Prices, Haircuts and Maturity
}

by Tamon Asonuma, Dirk Niepelt and Romain Ranciere

IMF Working Papers describe research in progress by the author(s) and are published to elicit comments and to encourage debate. The views expressed in IMF Working Papers are those of the author(s) and do not necessarily represent the views of the IMF, its Executive Board, or IMF management.

I N T E R N A T I O N A L M O N 


\section{WP/17/119}

\section{IMF Working Paper}

\section{Sovereign Bond Prices, Haircuts and Maturity}

by Tamon Asonuma, Dirk Niepelt and Romain Ranciere

IMF Working Papers describe research in progress by the author(s) and are published to elicit comments and to encourage debate. The views expressed in IMF Working Papers are those of the author(s) and do not necessarily represent the views of the IMF, its Executive Board, or IMF management.

I N T E R N A T I O N A L M O 


\title{
IMF Working Paper
}

\author{
Research Department \\ Sovereign Bond Prices, Haircuts and Maturity \\ Prepared by Tamon Asonuma, Dirk Niepelt and Romain Ranciere*
}

Authorized for distribution by Xavier Debrun

May 2017

This Working Paper should not be reported as representing the views of the IMF. The views expressed in this Working Paper are those of the author(s) and do not necessarily represent those of the IMF or IMF policy. Working Papers describe research in progress by the author(s) and are published to elicit comments and to further debate.

\begin{abstract}
Rejecting a common assumption in the sovereign debt literature, we document that creditor losses ("haircuts") during sovereign restructuring episodes are asymmetric across debt instruments. We code a comprehensive dataset on instrument-specific haircuts for $28 \mathrm{debt}$ restructurings with private creditors in 1999-2015 and find that haircuts on shorter-term debt are larger than those on debt of longer maturity. In a standard asset pricing model, we show that increasing short-run default risk in the run-up to a restructuring episode can explain the stylized fact. The data confirms the predicted relation between perceived default risk, bond prices, and haircuts by maturity.
\end{abstract}

JEL Classification Numbers: F34; F41; H63.

Keywords: Sovereign Debt; Default; Debt Restructuring; Bond Prices; Haircuts; Maturity; Default Probability.

Author's E-Mail Address: TAsonuma@imf.org, dirk.niepelt@szgerzensee.ch, romainranciere@gmail.com.

\footnotetext{
* Tamon Asonuma is an economist in the Research Department. Dirk Niepelt is the Director of the Study Center Gerzensee and a professor at the University of Bern. Romain Ranciere is a professor at the University of Southern California. The authors are grateful to Christoph Trebesch for kindly providing the data. The authors thank Fernando Broner, Luis Catao, Marcos Chamon, Satyajit Chatterjee, Xavier Debrun, Raphael Espinoza, Raquel Fernández, Atish Rex Ghosh, Anastasia Guscina, Juan Carlos Hatchondo, Olivier Jeanne, Luc Laeven, Alberto Martin, Leonardo Martinez, Michael G. Papaioannou, Fabrizio Perri, Guido Sandleris, Damiano Sandri, Sergio Schmukler, Christoph Trebesch, Adrien Verdelhan, Pablo Winant, Mark Wright and participants at 2015 Barcelona GSE Summer Forum (International Capital Flows), IMF ICD, IMF RES, 2016 North American Winter Meeting of the Econometric Society (San Francisco), UC Santa Cruz, and Univ. Osaka for comments and suggestions.
} 


\section{Contents}

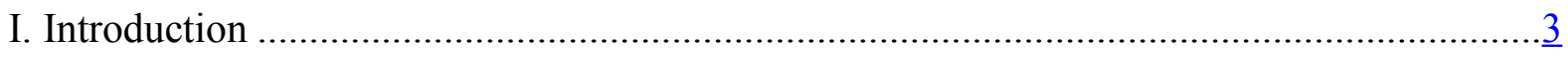

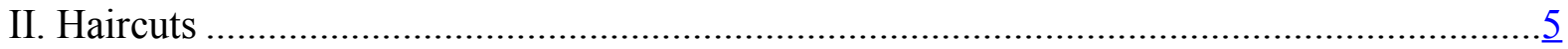

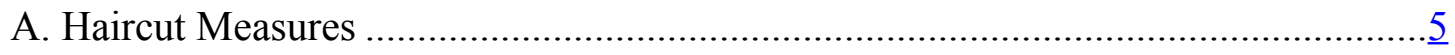

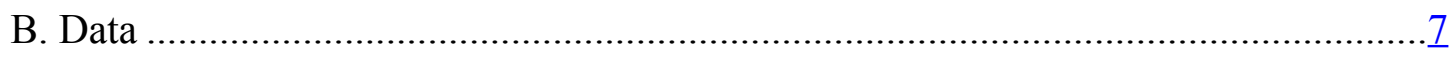

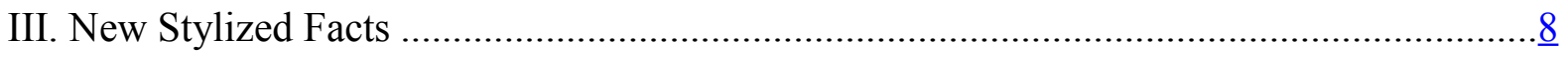

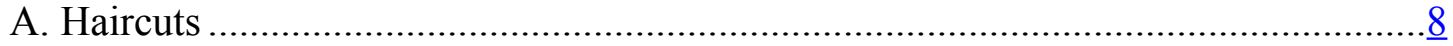

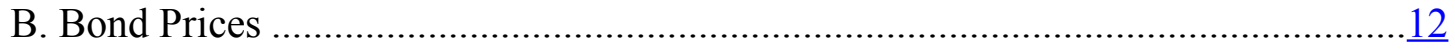

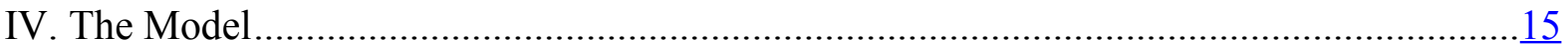

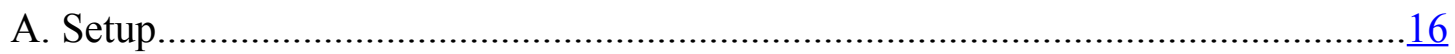

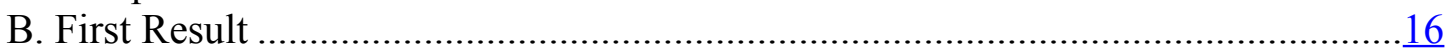

C. Second Result .................................................................................

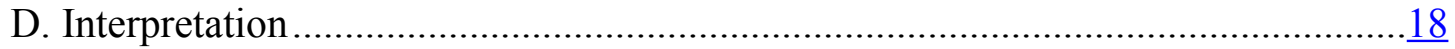

V. Default Probability Term Structure...................................................................

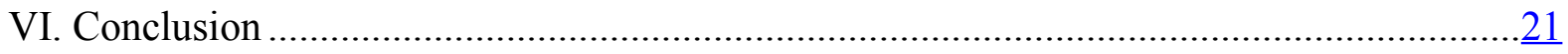

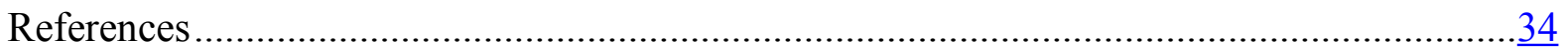

Figures

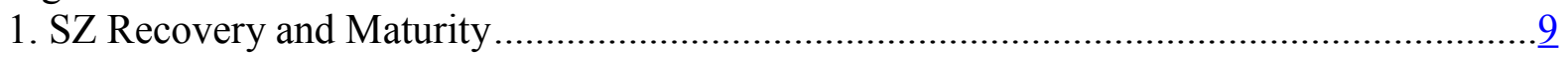

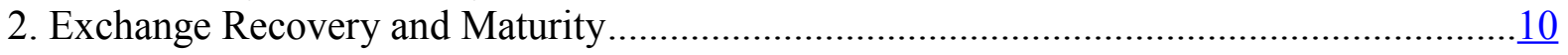

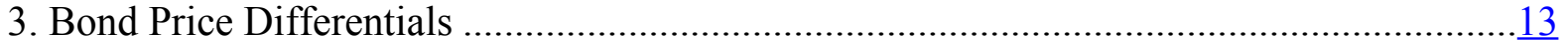

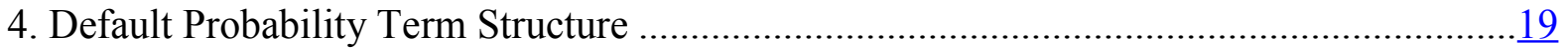

Tables

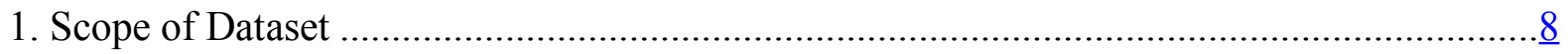

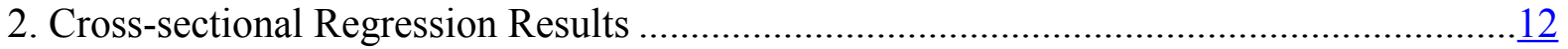

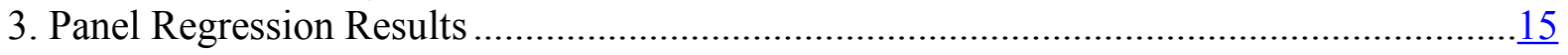

4. Panel Regression Results ..............................................................................

Appendices

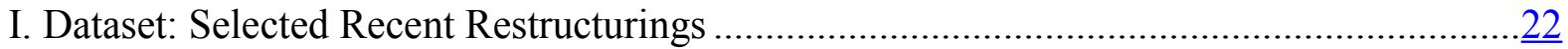

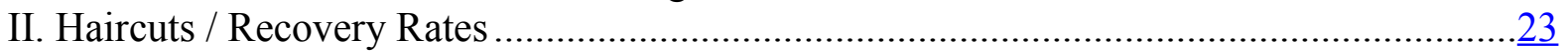

III. SZ Haircuts Robustness Check ........................................................................... 27

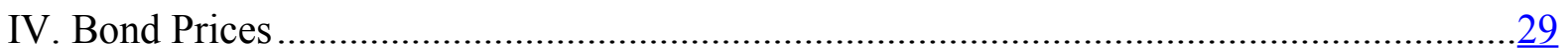

V. Estimation of Term Structure of Default Risk ....................................................... $\frac{31}{33}$

VI. Default Probability Term Structure ........................................................................ 


\section{INTRODUCTION}

Conventional wisdom among practitioners and academics holds that the treatment of private creditors in sovereign debt exchanges does not vary by the maturity of instruments they hold (Institute of International Finance 2012; 2015). ${ }^{1}$ After all, the pari passu clause, which is commonly included in unsecured cross-border corporate and international sovereign debt contracts, provides that the debt instruments issued under such contracts will rank equally among themselves and with all other present or future unsubordinated and unsecured external debt obligations of the borrower (IMF 2014). In line with this view, the empirical literature on sovereign debt restructurings has documented that creditor losses ("haircuts") tend to be symmetric across private debt instruments-with a few exceptional restructuring episodes (Sturzenegger and Zettelmeyer 2006, 2008).

In this paper, we challenge the conventional wisdom. Based on a new, comprehensive dataset on instrument-specific haircuts in 28 sovereign debt restructuring episodes (18 external and 10 domestic) with private creditors over the period 1999-2015, we document that creditor losses systematically vary by maturity of debt instrument. Specifically, we show that haircuts on shorter-term debt tend to be larger.

Our finding is robust. It holds when we measure haircuts according to the standard Sturzenegger and Zettelmeyer $(2006,2008)$ measure which is computed based both on a market price and a hypothetical net present value. It also holds when we measure haircuts alternatively, based on the price of the "old" instrument before the exchange relative to the price of the "new" instrument immediately after the restructuring. Our alternative measure can easily be computed because it only requires observed market prices. Moreover, it can be computed for windows of different length before the actual restructuring date.

Our finding also is robust when we control for characteristics of the exchanged bonds or the restructuring episode. For instance, it holds both in external and domestic restructuring episodes; it holds when restructurings occur preemptively or post default ${ }^{2}$; and it holds independently of the exchange method that is, whether the exchange involves a single menu of new instruments or different menus depending on type of restructured bonds. ${ }^{3}$ Cross-

\footnotetext{
${ }^{1}$ IMF (2015) documents that the terms of exchange often differ along other dimensions including governing law, currency denomination, type of instrument, and residency of debt holder.

${ }^{2}$ Asonuma and Trebesch (2016) define a restructuring as preemptive when the exchange takes place prior to or without a missed payment, and as post-default otherwise.

${ }^{3}$ In the restructuring cases where the exchange involves different menus depending on type of restructured bonds, short-term bond holders are often offered menus which include compensations for estimated creditor losses, i.e. cash payments ("sweeteners").
} 
sectional regressions controlling for instrument- and episode-specific effects robustly confirm the stylized fact.

Digging deeper, we find that the negative relation between the maturity of a bond and the haircut suffered during a debt exchange reflects the fact that ceteris paribus, short-term bond prices tend to be higher before an exchange than the prices of longer-term debt. In other words, in the run-up to a restructuring episode, short-term bond prices tend to converge to long-term bond prices from above.

Building on a standard model of arbitrage-free risk-neutral pricing we motivate the stylized fact as the natural implication of the term structure of default risk and its time variation. As long as investors anticipate strictly positive default risk after the maturity date of short-term debt, the price of the latter exceeds the price of longer-term debt (holding all other characteristics constant). Prices of short-term bonds therefore exceed prices of longer-term bonds, and when a restructuring episode ends with all outstanding instruments being exchanged against the same new instrument (or basket of new instruments) then this implies our main stylized fact: A higher haircut on short-term bonds, measured either way. Moreover, if in the run-up to a debt restructuring episode investors perceive increasingly short-term default risk then the prices of short- and longer-term bonds converge. This implies that the extent to which the possible haircuts vary by maturity weakens as the restructuring event approaches. Intuitively, successive bad news in the run-up to the restructuring compress price differentials across maturities and as a consequence, diminish the ex-post haircut differentials as well.

We then explore empirically the theoretical prediction that prices of short- and longer-term bonds converge because of increasingly short-term default risk. In panel regressions covering the period from 6 months before the announcement of a restructuring until the date of exchange or default, and controlling for restructuring-specific factors we find that the data confirms the prediction.

Our paper relates to the empirical literature on creditor losses due to restructurings, specifically Eichengreen and Portes (1986, 1989), Lindert and Morton (1989), Sturzenegger and Zettelmeyer (2006, 2008), Benjamin and Wright (2009), Cruces and Trebesch (2013), Finger and Mecagni (2007), Bedford et al., (2005), as well as Diaz-Cassou et al., (2008). ${ }^{4}$ Almost all studies report the average haircuts for the restructuring. ${ }^{5}$ Only a few (Sturzenegger and Zettelmeyer 2006, 2008; and Zettelmeyer et al., 2013) document instrument-specific haircuts, but only for selected restructuring episodes. In contrast, we report instrumentspecific haircuts for a large sample of restructuring episodes; we document a novel stylized

\footnotetext{
${ }^{4}$ Cline (1995) and Rieffel (2003) contain further haircut estimates for several episodes.

${ }^{5}$ Applying a similar approach, Hatchondo et al. (2014) measure average capital gains on restructured debt.
} 
fact concerning the systematic relationship between haircuts and maturity; and we offer an explanation for this fact.

Our paper also contributes to the theoretical literature building on Eaton and Gersovitz' (1981) classic framework and studying the maturity structure of sovereign debt for instance Rodrik and Velasco (1999), Jeanne (2009), Broner et al., (2013), Arellano and Ramanarayanan (2012), Chatterjee and Eyigungor (2012), Fernandez and Martin (2014), Aguiar and Amador (2014), Hatchondo and Martinez (2009), Hatchondo et al., (2015), and Niepelt (2014). These papers aim at rationalizing why sovereigns choose a specific portfolio composition, often assuming that haircuts after default are symmetric across bonds with different maturities. We document that this assumption is not supported by the data, and we offer an explanation for this new stylized fact which, as we also show, is consistent with other evidence.

The remainder of the paper is structured as follows. Section II explains two measures of creditor losses (haircuts) and our dataset. Section III documents the stylized facts on haircuts and bond price dynamics. Section IV presents a theoretical model of sovereign bond prices. Section $\mathrm{V}$ derives the estimated default probability term structure. A brief conclusion summarizes our discussion.

\section{Haircuts}

We construct a new dataset covering 28 sovereign debt restructuring episodes over the period 1999-2015. The dataset documents the size of private creditor losses (haircuts) for individual debt instruments based on two measures. First, the well-known Sturzenegger and Zettelmeyer $(2006,2008)$ measure. And second, the market price of the new debt instrument received in exchange for an old debt security, relative to the price of the old instrument at some date prior to the exchange.

\section{A. Haircut Measures}

Sturzenegger and Zettelmeyer (2006, 2008, SZ from now on) propose a haircut measure that is widely used among academics and increasingly so among practitioners as well. ${ }^{6} \mathrm{SZ}$ define the recovery rate (one minus the haircut) as the ratio of the net present values of two cash flow streams, a "new" one and an "old" one. The new cash flow stream reflects the contractually defined payments of the new debt instrument(s) received in the course of a debt exchange; the cash flows are discounted at the yield to maturity of the new instrument(s). The old cash flow stream reflects the contractually defined payments of the old debt instrument that was exchanged; these cash flows are also discounted at the yield to maturity of the new instrument(s).

\footnotetext{
${ }^{6}$ SZ haircuts differ from "market haircuts" used by financial market participants which compare the market value of new debt and cash received to the sum of outstanding face value of the old debt and past due interests (Sturzenegger and Zettelmeyer 2006, 2008).
} 
Let $N P V_{t}(i, r)$ denote the net present value as of time $t$ of the contractually defined cash flow stream of a debt instrument $i$ when the stream is discounted at the interest rate $r$. Moreover, let $e$ denote the new, exchanged debt instrument. Formally, the SZ recovery rate measure for instrument $i$ exchanged at date $T$ is defined as

$$
S Z R_{T}^{i} \equiv \frac{N P V_{T}\left(e, r_{T}^{e}\right)}{N P V_{T}\left(i, r_{T}^{e}\right)}
$$

where $r_{T}^{e}$ denotes the yield to maturity of instrument $e$ at the tine of the exchange (exit yield).

By definition, the price of a bond equals the present discounted value of its contractually defined cash flow stream when the cash flows are discounted at the yield to maturity. Formally, letting $p_{t}^{i}$ denote the ex-coupon price of instrument $i$ at date $t$,

$$
p_{t}^{i} \equiv N P V_{t}\left(i, r_{t}^{i}\right)
$$

This implies that the numerator in the SZ recovery rate measure can directly be observed: it is the price of the new, exchanged debt instrument immediately after the exchange. In contrast, the denominator of the measure cannot directly be observed and does not have a meaningful price counterpart: it represents the present discounted value (at the time of the exchange) of the old debt instrument's cash-flow stream when discounted at the new instrument's exit yield. Computing the denominator and thus, the SZ recovery rate requires information about the cash flow stream of the old instrument as well as the exit yield of the new instrument.

This information requirement poses a problem if one wishes to assess haircuts for many instruments, as we do. An obvious solution is to replace the net present value in the denominator of the SZ measure by a different net present value that equals an observed market price. This is easily achieved by replacing the exit yield in the net present value formula by the yield to maturity of the old instrument before the exchange. An additional advantage of this approach is that it opens the way for computing haircut measures that are defined over longer "windows."

We therefore define the alternative recovery rate measure, "Exchange recovery rate"

$$
R_{t, T}^{i} \equiv \frac{N P V_{T}\left(e, r_{T}^{e}\right)}{N P V_{t}\left(i, r_{t}^{i}\right)}
$$

which is, by definition, identical to the ratio of two prices. The numerator on the right-hand side of equation (2), which is the same as in equation (1), equals the price of the new instrument immediately after the exchange. The denominator equals the price of the old instrument at some date prior to the exchange, $t \leq T$.

Note that our new measure differs from the SZ measure even for $t=T$. This difference reflects the fact that the two measures use different base values to assess the recovery rate. 
While SZ use a synthetic value as base value, our measure (computed for $t=T$ ) uses the market price of the old instrument. In our empirical analysis, we find that quantitatively this difference is minor,

$$
\frac{R_{T, T}^{i}}{S Z R_{T}^{i}}=\frac{N P V_{T}\left(i, r_{T}^{e}\right)}{N P V_{T}\left(i, r_{T}^{i}\right)} \approx 1
$$

While for a single instrument, the dependence of $R_{t, T}^{i}$ on window length $T-t$ may be of limited interest, the differential dependence for different instruments does provide useful information. In particular, for two instruments $i$ and $j$ and varying window lengths, $T-t$, the relative recovery rates, $R_{t, T}^{i}-R_{t, T}^{j}$, illustrate which instrument's price converged more quickly to the market value of the new instruments received in the exchange.

\section{B. Data}

Our empirical analysis covers 28 episodes with 18 external and 10 domestic sovereign debt restructurings that involved private creditors, over the period 1999-2015. To date an episode, we rely on Asonuma and Papaioannou (2016) and Asonuma and Trebesch (2016) for domestic and external restructuring episodes, respectively. Following these authors, we define the start of an episode as the month in which a default occurs or a distressed restructuring is announced; and the end of an episode as the month of the final agreement or of the implementation of the debt exchange. ${ }^{7}$

We construct a novel comprehensive dataset with information about instrument specific haircuts according to the two measures defined previously. For each instrument $i$, we collect information on its maturity, coupon, payment type, and options. Moreover, we collect the same information for each new instrument $e$ that investors received in exchange for $i$. We collect this information from several sources: Offering memoranda, press releases from governments, financial sector databases and reports, IMF staff reports, SZ, Cruces and Trebesch (2013), and Asonuma and Papaioannou (2016). For information on market yields of the instruments and on market prices, we rely on financial sector databases such as Bloomberg, Datastream, Dealogic, and JP Morgan Markit.

Table 1 provides information about the scope of our dataset. With data on haircuts according to the SZ measure for 449 instruments in 18 external and 10 domestic sovereign debt restructuring episodes, it contains more than twice the number of observations than SZ. In addition, it contains information on haircuts according to our new measure (Exchange haircuts) for 111 instruments in 12 external and 6 domestic debt restructurings. The smaller number of observations for the new measure is due to the more limited information on bond yields and prices. Where price data is available, the dataset collects information for $R_{t, T}^{i}$ from

\footnotetext{
${ }^{7}$ Following Standard \& Poor's definition, distressed restructurings involve terms that are less favorable than the original terms of the bonds or loans.
} 
6-9 months prior to the announcement of the restructuring to the exchange in monthly frequency. Appendix I provides an overview over the restructuring episodes included in our sample.

Table 1. Scope of Dataset

\begin{tabular}{ccc} 
& \multicolumn{1}{c}{ Our data } & $\begin{array}{c}\text { Sturzenegger and } \\
\text { Zettelmeyer (2006, 2008) }\end{array}$ \\
\hline \hline SZ Haircuts & 28 restructurings & 11 restructurings \\
(Recovery Rates) & -18 external & -8 external \\
& 449 instruments & -3 domestic \\
& - only at exchange & 199 instruments \\
& - only at exchange \\
\hline \hline & 18 restructurings & \\
Exchange Haircuts & -12 external & \\
(Recovery Rates) & 111 instruments \\
& - from 6-9 months before the \\
& announcement of restructuring \\
& to the exchange \\
\hline \hline
\end{tabular}

\section{NEW STYLIZEd FACTS}

Our comprehensive instrument-specific dataset reveals two new stylized facts which are the main findings of the paper. First, using either of the measures defined in Section II, we document the following: Haircuts on shorter-term bonds tend to be larger than those on bonds of longer maturity. Second, we find that the negative relation between the maturity of a bond and the haircut suffered during a debt exchange reflects the fact that ceteris paribus, short-term bond prices tend to be higher before an exchange than the prices of longer-term debt.

\section{A. Haircuts}

\section{Stylized fact 1 - Haircuts on short-term bonds are larger than those on longer-term bonds.}

Figure 1 reports recovery rates according to $\mathrm{SZ}, S Z R_{T}^{i}$, by maturity for two restructuring episodes: Russia 1998-2000 (external) and Dominica 2003-2004 (domestic). Figure A1 in Appendix II reports two additional episodes: Belize 2006-2007 (external) and Saint Kitts and Nevis 2011-2012 (external). In all these cases and in many more not reported in the Figures, recovery rates on short-term bonds are substantially smaller than those on longer-term bonds. This holds true independently of the type of debt (e.g., external debt in Russia 1998-2000 or Greece 2011-2012 vs. domestic debt in Uruguay 2003 or Cyprus 2013), the restructuring strategy (e.g., preemptive restructuring in Greece 2011-2012 or Cyprus 2013 vs. post-default 
restructuring in Ecuador 1999-2000 or Russia 1998-2000), or the exchange method (e.g., exchange against a new instrument from a single menu in Greece 2011-2012 or Saint Kitts and Nevis 2011-2012 vs. new instruments from different menus in Cyprus 2013 or Ukraine 2000). In Appendix III, we document that these results are robust to employing modified SZ recovery rate measures based on higher or lower yields (exit yield $+/-1$ percent).

We obtain the same qualitative finding when we use our alternative recovery rate measure, $R_{t, T}^{i}$. Figure 2 reports $R_{t, T}^{i}$ by maturity for two restructuring episodes: Pakistan 1999 (external), and Cyprus 2013 (domestic). Figure A2 in Appendix II reports two additional cases: Greece 2011-2012 (external) and Uruguay 2003 (domestic). ${ }^{8}$ Moreover, Figure A3 and Table A2 in Appendix II show that our results remain robust when we evaluate our alternative recovery rate measures at different points in time, i.e. 6 months before and after the announcement of restructurings.

Figure 1. SZ Recovery and Maturity

(A) Russia 1998-2000 External

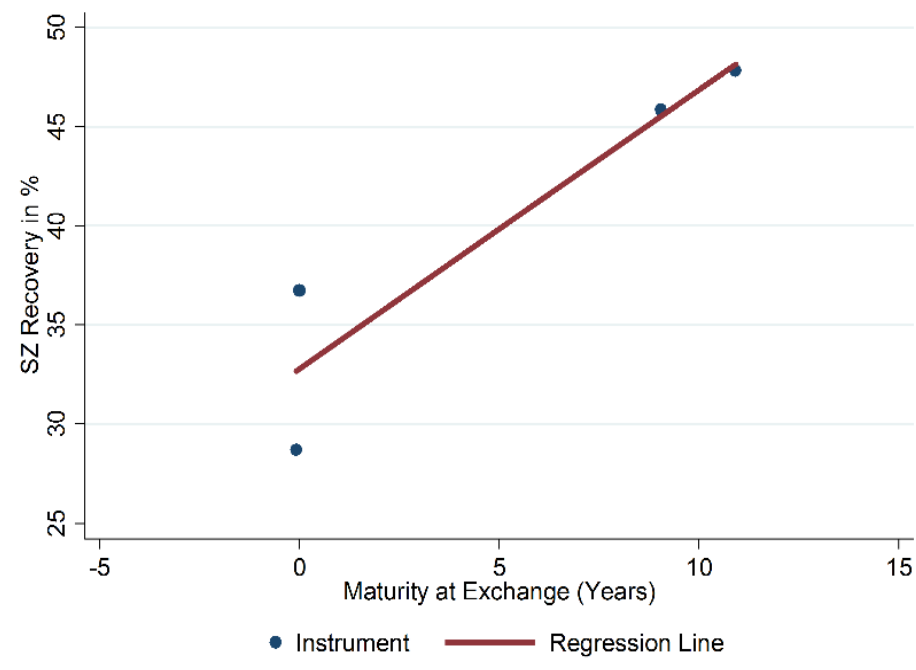

(B) Dominica 2003-2004 Domestic

\footnotetext{
${ }^{8}$ We see the same pattern in the external debt restructuring in Uruguay 2003.
} 


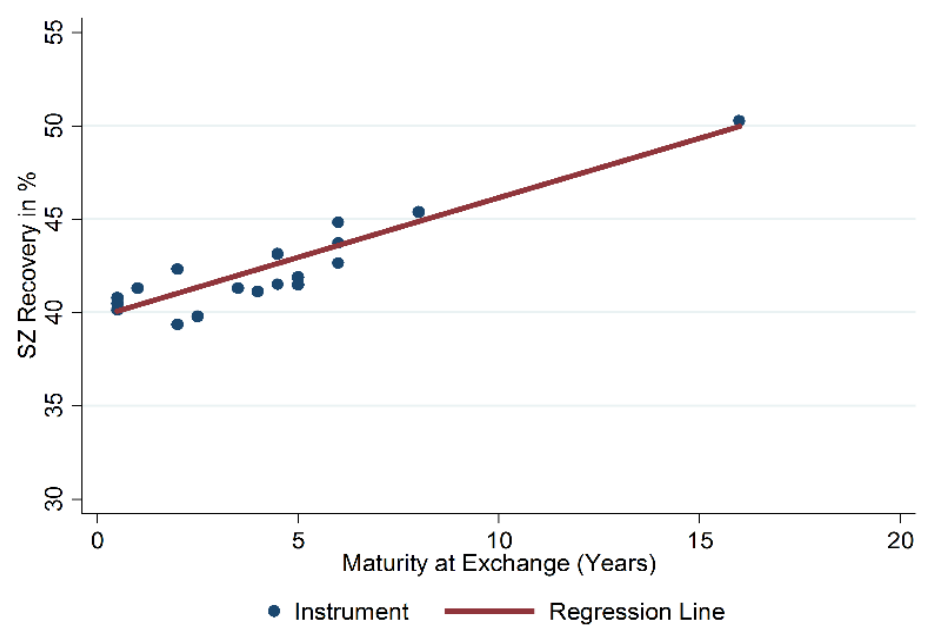

Figure 2. Exchange Recovery and Maturity

(A) Pakistan 1999 External

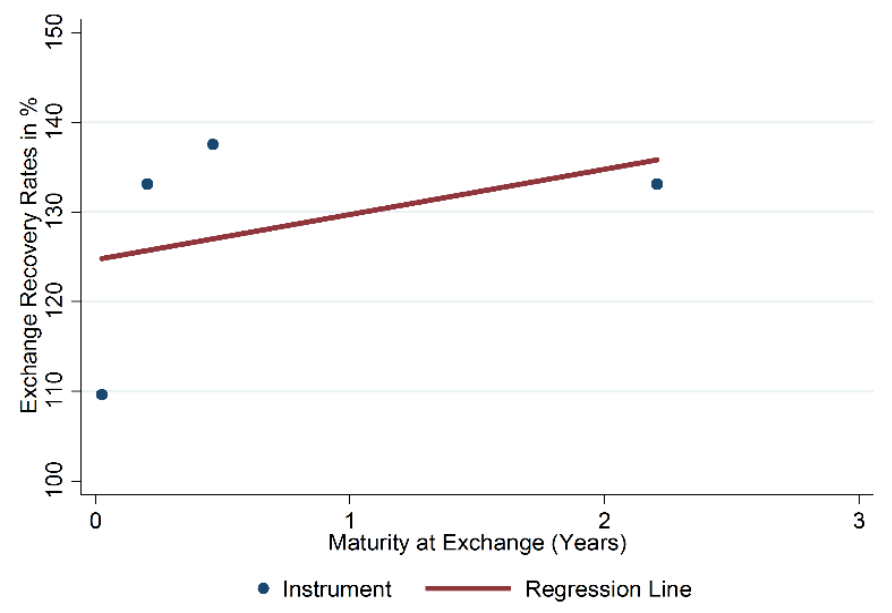

(B) Cyprus 2013 Domestic

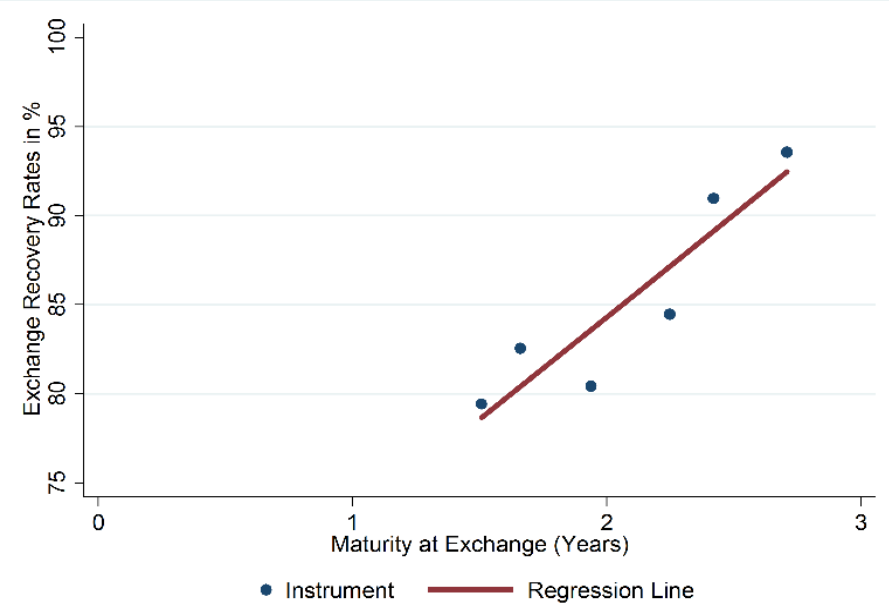


Table 2 provides econometric support for the stylized fact. It reports the results of a crosssectional regression of the recovery rate (measured according to $\mathrm{SZ}$ or our measure) on maturity as well as additional instrument- and episode-specific controls:

$$
\text { RecoveryRate }_{j}^{i}=c+\beta_{1} \text { Maturity }_{j}^{i}+\beta_{2} x_{j}^{i}+\beta_{3} y_{j}+c_{j}+\epsilon_{i, j}
$$

Here, Maturity $j_{j}^{i}$ denotes the remaining maturity of instrument $i$ at the date of exchange in restructuring episode $j ; x_{j}^{i}$ is a vector of instrument-specific variables, such as the coupon rate, a dummy in case of a floating coupon rate, a dummy for the type of amortization profile (amortization only at maturity,["bullet"] vs. already before maturity); $y_{j}$ is a vector of episode-specific variables, such as the duration of the restructuring and the type of debt (domestic or external); and $c_{j}$ is an episode-specific fixed effect.

The main result reported in Table 2 is that the effect of maturity on recovery rates (both according to $\mathrm{SZ}$ and our measure) is positive and significant at the 1-percent level.

Quantitatively, the effect is significant as well: on average, the recovery rate on a 10-year bond is 3-12 percentage points higher than on a 1-year bond. Columns (2) and (4) also reveal the effects of other controls. Instruments with high fixed coupon rates or with floating rates experience smaller recovery rates. The sign of the effect of the amortization profile is not precisely estimated. Because of different sample sizes, the effect of restructuring duration on the recovery rate identified in specification (2); the former is positive and significant. 
Table 2. Cross-sectional Regression Results

\begin{tabular}{|c|c|c|c|c|}
\hline & $\begin{array}{l}\text { SZ Recovery } \\
\text { Rate }\end{array}$ & $\begin{array}{l}\text { SZ Recovery } \\
\text { Rate, with } \\
\text { controls }\end{array}$ & $\begin{array}{c}\text { Exchange } \\
\text { Recovery Rate } \\
\text { (announcement) }\end{array}$ & $\begin{array}{c}\text { Exchange } \\
\text { Recovery Rate, } \\
\text { with controls }\end{array}$ \\
\hline & (1) & (2) & (3) & (4) \\
\hline & coef/se & coef/se & coef/se & coef/se \\
\hline $\begin{array}{l}\text { Maturity of Instrument } \\
\text { (years) }\end{array}$ & $\begin{array}{c}0.30 * * * \\
(0.08)\end{array}$ & $\begin{array}{c}0.35^{* * *} \\
(0.08)\end{array}$ & $\begin{array}{c}1.03 * * * \\
(0.30)\end{array}$ & $\begin{array}{c}1.24 * * * \\
(0.29)\end{array}$ \\
\hline $\begin{array}{l}\text { Coupon rate } \\
\text { (fixed, percent) }\end{array}$ & & $\begin{array}{c}-0.89 * * * \\
(0.18)\end{array}$ & & $\begin{array}{c}-3.08 * * * \\
(0.79)\end{array}$ \\
\hline $\begin{array}{l}\text { Coupon rate } \\
\text { (float, dummy) }\end{array}$ & & $\begin{array}{c}-8.69 * * * \\
(1.95)\end{array}$ & & $\begin{array}{c}-32.23 * * * \\
(11.80)\end{array}$ \\
\hline $\begin{array}{l}\text { Amortization profile (payment } \\
\text { before maturity, dummy) }\end{array}$ & & $\begin{array}{l}2.92 * \\
(1.70)\end{array}$ & & $\begin{array}{l}-14.07 \\
(8.97)\end{array}$ \\
\hline $\begin{array}{l}\text { Duration of Restructuring } \\
\text { (years) } \\
\text { External Debt Restructuring } \\
\text { (dummy) }\end{array}$ & & $\begin{array}{c}17.55 * * \\
(8.44) \\
-2.43 \\
(5.47)\end{array}$ & & \\
\hline Constant & $\begin{array}{l}52.00^{* * *} \\
(0.55)\end{array}$ & $\begin{array}{l}41.02^{* * *} \\
(9.94)\end{array}$ & $\begin{array}{l}78.77 * * * \\
(2.64)\end{array}$ & $\begin{array}{l}104.06^{* * *} \\
\quad(6.82)\end{array}$ \\
\hline Episode Fixed Effects & Yes & Yes & Yes & Yes \\
\hline Number of Countries & 15 & 15 & 12 & 12 \\
\hline Number of Restructurings & 28 & 28 & 16 & 16 \\
\hline Observations & 449 & 447 & 111 & 111 \\
\hline Adjusted $R$-Squared & 0.035 & 0.262 & 0.112 & 0.247 \\
\hline
\end{tabular}

The table reports results of fixed effects OLS regressions. The dependent variable is SZ recovery rate (columns 1 and 2) or Exchange recovery rate (columns 3 and 4) (in \%). The main explanatory variable is maturity of instrument at the time of exchange. The control variables are instrument-specific controls and restructuring-specific controls. Significance levels denoted by $* * * p<0.01, * * p<0.05, * p<0.10$. All regressions include restructuring-specific fixed effects. Robust standard errors in parentheses.

\section{B. Bond Prices}

\section{Stylized fact 2 - The difference in prices between short-term and longer-term bonds decreases in the run up to the debt exchange.}

Figure 3 reports bond price differentials-prices of short-term bonds minus prices of longerterm bonds. We present two episodes: (A) Ukraine 2000 external, and (B) Greece 2011-2012 external. Figure A6 in Appendix IV reports two additional episodes: (C) Dominican Republic 2004-2005 external (bonds) and (D) Argentina 2001-2005 external. In all figures, grey bars indicate the date of the announcement of restructuring. Both figures show that prices of short-term and long-term bonds converge in the run-up to the exchange. The observed price 
dynamics are not specific either to the type of debt (domestic or external) or the restructuring strategy (strictly preemptive, weakly preemptive or post-default).$^{9,10}$

Figure 3. Bond Price Differentials

(A) Ukraine 2000 External

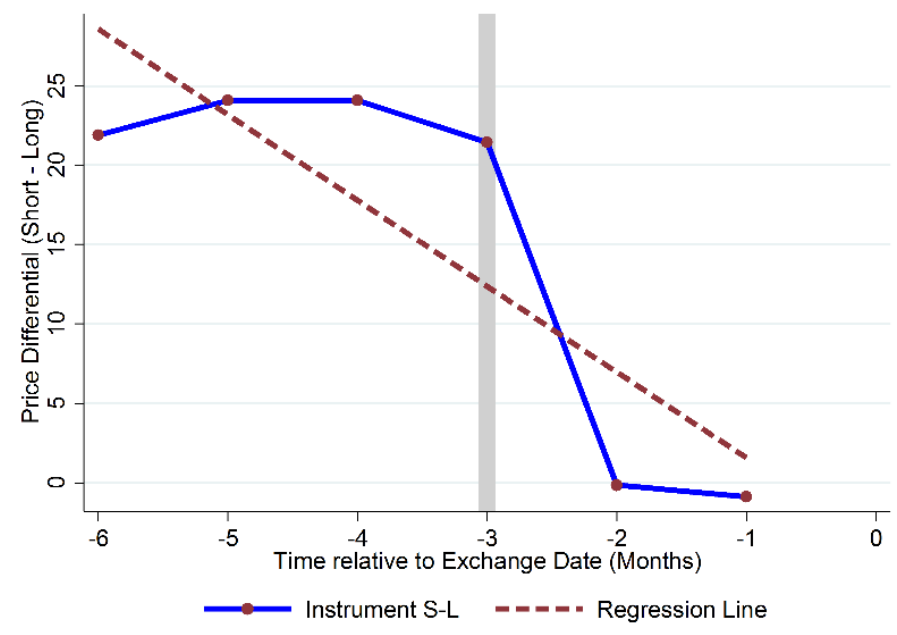

(B) Greece 2011-2012 External

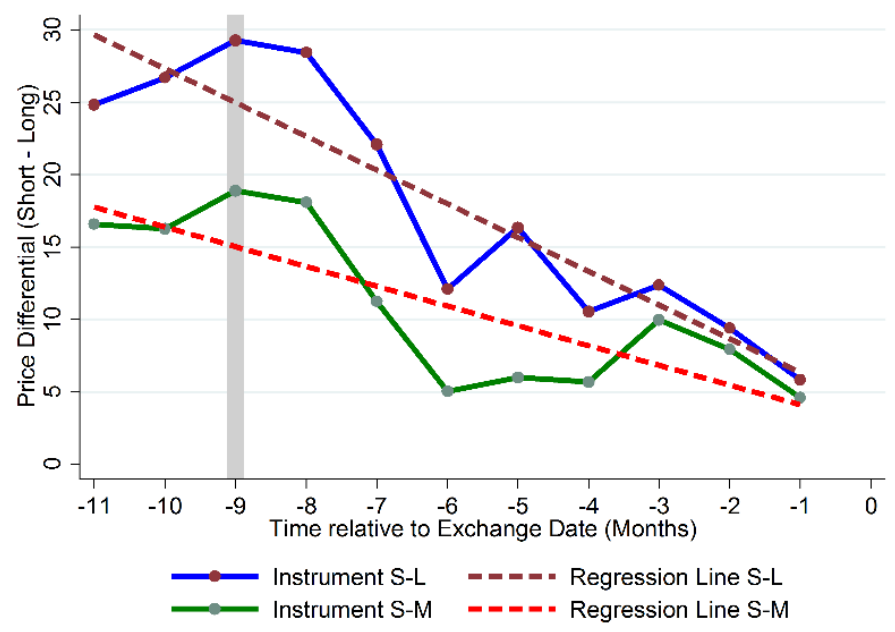

Note: Grey bars indicate the date of the announcement of restructuring.

Table 3 provides econometric support for this stylized fact. It reports results of panel regressions of the bond price differential on time relative to exchange date and maturity differential with additional instrument- and episode-specific controls:

\footnotetext{
${ }^{9}$ We exclude bonds that are no longer traded on the market.

${ }^{10}$ See Guscina et al. (2017) for two episodes of the flattening of the term structure prior to a distress event.
} 


$$
\Delta \text { Price }_{j, t}^{S / L}=c+\beta_{1} \text { Time }_{j, t}+\beta_{2} \Delta \text { Maturity }_{j}^{S / L}+\beta_{3} y_{j}+\epsilon_{j, t}
$$

where $\Delta$ Price $_{j, t}^{S / L}=$ Price $_{j, t}^{\text {Short }}-$ Price $_{j, t}^{\text {Long }}$ and $\Delta$ Maturity $_{j}^{S / L}=$ Maturity $_{j}^{\text {Short }}-$ Maturity $_{j}^{\text {Long }}$ denote bond price differential and maturity differential between short-term bonds and long-term bonds at time $t$ in debt restructuring $j$ respectively. Time $_{j, t}$ denotes the time span until the exchange date (in months) at time $t$ in debt restructuring $j . y_{j}$ denotes the same vector of episode-specific controls as in Section III.A.

The main result in Table 3 is that the price of short-term debt approaches the price of longerterm debt from above during the run-up to the exchange. This effect is significant at the 1percent level, and quantitatively large: over 6 months the price difference diminishes by 9 percentage points (relative to face value of 100). The second result concerns the size of the bond price differential conditional on time: it increases with the maturity differential. For instance, the price of a 1-year bond exceeds the price of a 10 -year bond by 4 percentage points. Once we decompose episode-specific fixed effects, we find that restructuring strategy (strictly preemptive vs post-default) and type of debt (external vs domestic) enter as a significant explanatory variable. Moreover, Argentina's 2001-2005 external debt restructuring appears to constitute an outlier in that ceteris paribus, the bond price differential was larger.

The speed of price convergence is approximately the same in the subsample of restructuring episodes where the exchange involves a single menu of new instruments vs different menus, see the results as reported in Table A3 in Appendix IV. 
Table 3. Panel Regression Results

\begin{tabular}{|c|c|c|c|}
\hline & $\begin{array}{l}\text { Bond Price } \\
\text { Differential }\end{array}$ & $\begin{array}{c}\text { Bond Price } \\
\text { Differential, with FE }\end{array}$ & $\begin{array}{l}\text { Bond Price Differential, } \\
\text { with controls }\end{array}$ \\
\hline & (1) & (2) & (3) \\
\hline & coef/se & coef $/ \mathrm{se}$ & coef/se \\
\hline $\begin{array}{l}\text { Time Span until the Exchange Date } \\
\text { (months) }\end{array}$ & $\begin{array}{c}-1.52 * * * \\
(0.08)\end{array}$ & $\begin{array}{c}-1.52 * * * \\
(0.08)\end{array}$ & $\begin{array}{c}-1.52 * * * \\
(0.08)\end{array}$ \\
\hline Maturity Differential & $-0.49 * * *$ & $-0.49 * * *$ & $-0.49 * * *$ \\
\hline (S - L, year) & $(0.05)$ & $(0.05)$ & $(0.05)$ \\
\hline $\begin{array}{l}\text { Duration of Restructuring } \\
\text { (years) }\end{array}$ & & & $\begin{array}{l}-10.39 \\
(7.92)\end{array}$ \\
\hline Argentina 2001-2005 & & & $43.67 * *$ \\
\hline Restructuring (dummy) & & & $(22.12)$ \\
\hline Strictly Preemptive Restructuring & & & $17.89 * *$ \\
\hline (dummy) & & & $(7.22)$ \\
\hline Weakly Preemptive Restructuring & & & 9.79 \\
\hline (dummy) & & & $(11.71)$ \\
\hline External Debt Restructuring & & & $16.56^{* *}$ \\
\hline (dummy) & & & $(7.07)$ \\
\hline Constant & 2.88 & $2.21 * * *$ & $-16.39 *$ \\
\hline & $(3.08)$ & $(0.60)$ & $(8.66)$ \\
\hline Episode Fixed Effects & No & Yes & No \\
\hline Number of Restructurings & 12 & 12 & 12 \\
\hline Number of Pairs of Instruments & 66 & 66 & 66 \\
\hline Observations & 605 & 605 & 605 \\
\hline Adjusted $R$-Squared & 0.224 & 0.429 & 0.429 \\
\hline \multicolumn{4}{|c|}{$\begin{array}{l}\text { Columns } 1 \text { and } 3 \text { report random effects OLS regression results and column } 2 \text { reports fixed effects } \\
\text { OLS regression result. The dependent variable is bond price differential (price of short-term bond - } \\
\text { price of long-term bond). The main explanatory variables are the time span until the exchange date (in } \\
\text { months) and maturity differential (maturity of short-term bond - maturity of long-term bond) at the time } \\
\text { of exchange. The control variables are episode-specific controls. Significance levels denoted by *** } \\
\mathrm{p}<0.01,{ }^{* *} \mathrm{p}<0.05, * \mathrm{p}<0.10 \text {. Robust standard errors in parentheses. }\end{array}$} \\
\hline
\end{tabular}

\section{THE MODEL}

To identify potential drivers of the observed positive correlation between bond maturity and recovery rate, we rely on a standard asset pricing model adapted to the sovereign debt context. We establish two results. First, prior to the run-up to a debt restructuring prices of short-term bonds exceed prices of longer-term bonds. When a restructuring episode ends with all outstanding instruments being exchanged against the same new instrument (or basket of new instruments), as is typically the case, then this first result implies the main stylized fact that we have documented in Section III: A higher haircut on short-term bonds. The first result also explains the correlation between haircut and maturity if the haircut is measured following Sturzenegger and Zettelmeyer's approach. Second, in the run-up to a debt restructuring prices of short- and longer-term bonds converge because default risk in the short-term rises. This second result implies that the extent to which haircuts vary by maturity weakens as the restructuring event approaches. Intuitively, successive bad news in the run-up 
to the restructuring compress price differentials across maturities and as a consequence, the ex-post haircut differences diminish as well.

\section{A. Setup}

To derive these results, consider a discrete time environment. In period $t$, a bond that matures in period $m$ either pays the predefined contractual payment, or the issuer announces a restructuring. ${ }^{11}$ In the former case, the bond pays the contractual coupon, $c^{m}$, if $t<m$; or the coupon plus principal (unity) if $t=m$. In the latter case, the bond pays a recovery value, $\phi_{t}^{m}$. The probability of no restructuring between periods $t$ and $s, s>t$, given that no such restructuring occurred until $t$, equals $\pi_{t, s}$.

The timing of events in each period $t$ is as follows: At the beginning of the period, investors learn whether a restructuring "shock" has occurred, that is whether debt will be restructured and thus pay off $\phi_{t}^{m}$. They may also receive new information about future restructuring risk that may lead them to update their beliefs about $\pi_{t, s}$. Conditional on the (new) information, the bond pays the contractual payment or the recovery value, and in the former case the excoupon price materializes.

To keep the notation simple, we assume that investors are risk neutral and the risk-free gross interest rate is time invariant and equal to $\beta^{-1}$. Standard asset pricing then implies that the ex-coupon price equals the expected discounted price and coupon payment in the subsequent period conditional on no restructuring, plus the expected discounted recovery value if a restructuring shock hits in the subsequent period. Formally, letting $p_{t}^{m}$ denote the ex-coupon price at date $t$ of a bond maturing at date $m$,

$$
\mathrm{p}_{t}^{m}=\beta\left\{\pi_{t, t+1}\left(c^{m}+\mathbb{E}_{t}\left[\mathrm{p}_{t+1}^{m} \mid N_{t+1}\right]\right)+\left(1-\pi_{t, t+1}\right) \mathbb{E}_{t}\left[\phi_{t+1}^{m} \mid A_{t+1}\right]\right\}
$$

where $N_{t+1}$ and $A_{t+1}$ denote "no announcement of restructuring in period $t+1$ (and earlier)" and "announcement of restructuring in period $t+1$," respectively. In the last period before maturity, $t=m-1$, the equation holds with $p_{t+1}^{m}=1$.

\section{B. First Result}

Let $\Delta_{t}^{s, l} \equiv p_{t}^{s}-p_{t}^{l}$ denote the price difference between a short-term bond with maturity date $s$ and a longer-term bond with maturity date $l .{ }^{12}$ With identical coupons and recovery values across bonds, $\mathrm{c}^{s}=c^{l}$ and $\phi_{i}^{s}=\phi_{i}^{l}$ for all $i \leq s$, we have

\footnotetext{
${ }^{11}$ For reasons outside the model (e.g., concerns about financial stability) Treasury bills and trade finances often are treated favorably in debt exchanges. In the empirical analysis, we exclude these instruments.

12 This price difference is given by
}

(continued...) 


$$
\Delta_{t}^{s, l}=\beta^{s-t} \pi_{t, s} \mathbb{E}_{t}\left[\Delta_{s}^{s, l} \mid N_{s}\right]
$$

That is, if a positive price difference is expected to prevail at date $s$-which holds true whenever the longer-term bond is exposed to sufficiently high default risk after period $s$ (or when it has a sufficiently low coupon)-then the current price difference is positive as well. This positive relationship between the current price difference and the expected future price difference only collapses when the coupon or the recovery values of the longer-term bond are sufficiently large relative to those of the short-term bond.

Absent major such differences between the coupons or the recovery values, long-term restructuring risk (and $\mathbb{E}_{t}\left[\Delta_{s}^{s, l} \mid N_{s}\right]>0$ ) therefore implies $\Delta_{t}^{s, l}>0$ : Short-term bonds are more expensive than longer-term bonds. This constitutes the first result stated before.

\section{Second Result}

Over time, $\Delta_{t}^{s, l}$ may change for two fundamentally different reasons. First, because time passes by. And second, because news arrives, in particular about future restructuring risk. With identical coupons and recovery values across bonds, the price difference evolves according to

$$
\Delta_{t+1}^{s, l}-\Delta_{t}^{s, l}=\beta^{s-t-1} \pi_{t+1, s \mid t+1} \mathbb{E}_{t+1}\left[\Delta_{s}^{s, l} \mid N_{s}\right]-\beta^{s-t} \pi_{t, s \mid t} \mathbb{E}_{t}\left[\Delta_{s}^{s, l} \mid N_{s}\right]
$$

where the subscript of the probability of no restructuring now also indicates the information set. ${ }^{13}$

Absent new information, the change in the price difference reduces to

$$
\Delta_{t+1}^{s, l}-\Delta_{t}^{s, l}=\beta^{s-t-1} \pi_{t+1, s \mid t} \mathbb{E}_{t}\left[\Delta_{s}^{s, l} \mid N_{s}\right]\left(1-\beta \pi_{t, t+1 \mid t}\right)
$$

$$
\begin{aligned}
\Delta_{t}^{s, l} \equiv \beta\left\{\pi_{t, t+1}\right. & \left.\left(c^{s}-c^{l}+\mathbb{E}_{t}\left[\Delta_{t+1}^{s, l} \mid N_{t+1}\right]\right)+\left(1-\pi_{t, t+1}\right) \mathbb{E}_{t}\left[\phi_{t+1}^{s}-\phi_{t+1}^{l} \mid A_{t+1}\right]\right\} \\
& =\left(c^{s}-c^{l}\right) \sum_{i=t+1}^{s} \beta^{i-t} \pi_{t, i}+\sum_{i=t+1}^{s} \beta^{i-t} \pi_{t, i-1}\left(1-\pi_{i-1, i}\right) \mathbb{E}_{t}\left[\phi_{i}^{s}-\phi_{i}^{l} \mid A_{i}\right] \\
& +\beta^{s-t} \pi_{t, s} \mathbb{E}_{t}\left[\Delta_{s}^{s, l} \mid N_{s}\right]
\end{aligned}
$$

${ }^{13}$ That is, $\pi_{t+1, s \mid t}$ denotes the probability of no restructuring between periods $t+1$ and $s$ conditional on information at time $t$.

(continued...) 
which is positive under the assumptions leading to the first result discussed above. That is, absent new information prices further diverge. ${ }^{14}$

If new information implies sufficiently increased default risk in the short term, however, then $\Delta^{s, l}$ may fall over time. Intuitively, an increase of short-term default risk proportionally lowers the prices of short- and longer-term debt. In absolute terms, the price of short-term debt thus falls more strongly. ${ }^{15}$ This constitutes the second result. It reflects the fact that lower expected payoffs support lower contemporaneous prices. Note that the result continues to hold if new information about recovery values arrives as long as the recovery values are identical for bonds with different maturities.

\section{Interpretation}

By selecting episodes leading to restructuring we implicitly select episodes characterized by rising short-term default risk. Ceteris paribus, the model predicts the price difference $\Delta^{s, l}$ to be positive during such episodes but decreasing over time. The positive price difference explains the empirical finding of higher haircuts on shorter-term debt. The decreasing price difference explains the empirical finding that the relation between maturity and haircut is weaker when the restructuring is closer.

\section{Default Probability Term Structure}

We have argued in Section IV that basic theory explains the two stylized facts-higher haircuts on short-term bonds and smaller haircut differences with shorter window length-if short-term default risk rises in the run-up to a restructuring. We now investigate empirically the relation between bond prices and short-term default risk. In line with theory, we document an additional stylized fact: in the run-up to an exchange the term structure of default risk becomes elevated at the short end.

\section{Stylized fact 3 -The term structure of default probability becomes elevated at the short end in the run-up to the exchange.}

Using the method introduced in Ranciere (2002), we estimate the term structure of default risk. In our estimation exercise, the main inputs are (a) the Credit Default Swap (hereafter CDS) spread curve, and (b) the US Treasury bill yield curve proxying for the risk-free interest curve. Following Ranciere (2002), we assume (i) no arbitrage, (ii) risk-neutrality, and (iii) the exchange involving a single menu of new instruments for all restructured instruments.

\footnotetext{
${ }^{14}$ Deterministic price divergence may also result due to different coupons or expected recovery values $\left(c^{s}<c^{l}\right.$ and $\phi^{s}<\phi^{l}$ ).

${ }^{15}$ The price difference might also fall if the expected future price difference is updated downward.
} 
Under these assumptions, we use annual yield curve data and linear interpolations to construct estimates of the CDS spread curve for horizons between 1 and 120 months, at the monthly frequency. Based on this, we use the no arbitrage condition to derive the forward default spread curve. This curve measures the implied one-month ahead conditional default risk. Finally, we use the risk-neutrality assumption and the fact that the exchange involves a single menu of new instruments for all restructured instruments to derive the implied onemonth ahead conditional default probability. Appendix V discusses the details.

Figure 4 reports our conditional default probability estimates at the 1 -year horizon. We present two cases: (A) Ecuador 1999-2000 external and (B) Greece 2011-2012 external. Figure A8 in Appendix VI reports the case of Argentina 2001-2005 external. In all figures, grey bars indicate the date of the restructuring announcement. Both figures show that the conditional short-term default probability (1 year) increases in the run-up to the exchange. This observed rise is not specific to restructuring strategy (strictly preemptive, weakly preemptive or post-default) and we also observe it at the 2-year and 3-year horizon, as reported in Table A4 in Appendix VI.

Figure 4. Default Probability Term Structure

(A) Ecuador 1999-2000 External

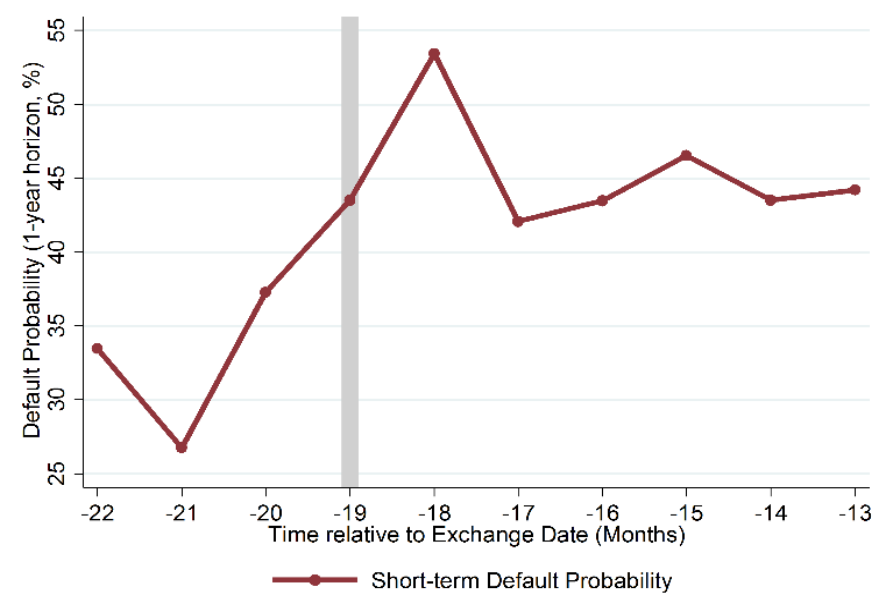


(B) Greece 2011-2012 External

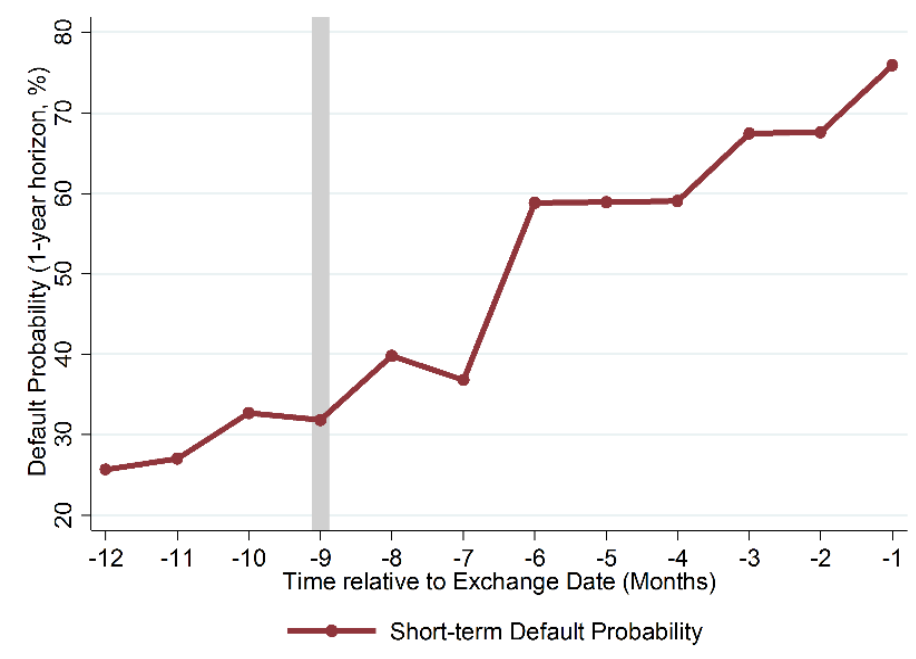

Note: Grey bars indicate the date of the announcement of restructuring.

Table 4 provides econometric support for the stylized fact. It presents results of panel regressions of the conditional default probability at the 1-year horizon on the time span until the exchange date with additional episode-specific controls:

$$
\text { Default }_{j, t}=c+\beta_{1} \text { Time }_{j, t}+\beta_{2} y_{j}+\epsilon_{j, t}
$$

where Default ${ }_{j, t}$ denotes the conditional default probability over the 1-year horizon at time $t$ in debt restructuring $j$. Time $e_{j, t}$ denotes the time span until the exchange at time $t$ in debt restructuring $j . y_{j}$ denotes the same vector of episode-specific controls as in Section III.A.

The main result in Table 4 is that the conditional default probability increases in the run-up to the exchange. This effect is significant at the 1-percent level, and quantitatively large: over 6 months the default risk increases by 7-16 percentage points. Once we decompose episodespecific fixed effects, we find that restructuring strategy (strictly preemptive vs post-default) enters as a significant explanatory variable. Duration of restructuring turns out to significantly reduce the conditional default probability possibly because default probability gradually increases for restructurings with longer duration. 
Table 4. Panel Regression Results

\begin{tabular}{lccc}
\hline \hline & $\begin{array}{c}\text { Default } \\
\text { Probability 1-Year } \\
\text { Horizon (\%) }\end{array}$ & $\begin{array}{c}\text { Default Probability } \\
1-\text { Year Horizon, } \\
\text { with FE }\end{array}$ & $\begin{array}{c}\text { Default Probability } \\
1-\text { Year Horizon, } \\
\text { with controls }\end{array}$ \\
\cline { 2 - 4 } & $(1)$ & $(2)$ & $(3)$ \\
\cline { 2 - 4 } & coef/se & coef/se & coef/se \\
\cline { 2 - 4 } Time Span until the Exchange Date & $1.09^{* * *}$ & $2.70^{* * *}$ & $2.70^{* * *}$ \\
(months) & $(0.26)$ & $(0.37)$ & $(0.37)$ \\
Duration of Restructuring & $-3.11^{* *}$ & & $-15.68^{* * *}$ \\
(years) & $(1.43)$ & & $(2.66)$ \\
Strictly Preemptive Restructuring & & & $-37.98^{* * *}$ \\
(dummy) & & $71.92^{* * *}$ & $(7.37)$ \\
Constant & $61.20^{* * *}$ & $(4.06)$ & $115.36^{* * *}$ \\
& $(4.61)$ & Yes & $(11.06)$ \\
Episode Fixed Effects & No & 3 & No \\
Number of Restructurings & 3 & 12 & 3 \\
Number of Time Periods (months) & 12 & 36 & 12 \\
Observations & 36 & 0.628 & 36 \\
Adjusted $R$-Squared & 0.373 & 0.628 \\
\hline \hline
\end{tabular}

Columns 1 and 3 report random effects OLS regression results and column 2 reports a fixed effects OLS regression result. The dependent variable is the conditional default probability at the 1-year horizon (\%). The main explanatory variable is the time span until the exchange date (in months). The control variables are episode-specific controls. Significance levels denoted by *** $\mathrm{p}<0.01, * * \mathrm{p}<0.05$, $* \mathrm{p}<0.10$. Robust standard errors in parentheses.

\section{CONCLUSION}

This paper studies creditor losses (haircuts) across sovereign debt instruments during debt restructurings. We show that, contrary to conventional wisdom, creditors are not treated equally in sovereign debt exchanges. We first construct a comprehensive dataset on instrument-specific haircuts in recent sovereign debt restructuring episodes affecting private creditors. We demonstrate that haircuts on shorter-term debt tend to be larger than those on longer-term debt, and propose a simple asset pricing model that can theoretically explain this fact. We also show that the data support the causal link among short-term default risk, bond prices and maturity-specific haircuts suggested by the model.

Our findings highlight a regularity that has not received much attention so far and has potential implications for important dimensions of debt policy including, pari passu and its limitations; the negotiation process during debt restructuring episodes; the value at risk of debt securities of different maturities (and thus, of financial institutions that hold these instruments); or the optimal debt management more broadly. However, further research is required before drawing normative conclusions or policy prescriptions, as the findings in this paper do not allow to conclude that specific bond maturities are better or worse than others for issuers or for investors. 
Appendix I. Dataset: Selected Recent Restructurings

Table A1. Selected Recent Sovereign Debt Restructurings (1998-2015)

\begin{tabular}{|c|c|c|c|c|c|}
\hline Episode & $\begin{array}{l}\text { Announcement } \\
\text { or Default (Start) }\end{array}$ & $\begin{array}{l}\text { Exchange } \\
\text { (End) }\end{array}$ & $\begin{array}{c}\text { Restructuring } \\
\text { Strategy }\end{array}$ & $\begin{array}{c}\text { SZ Haircut } \\
\text { Diffe re ntial (S- and } \\
\text { L-term, percent) }\end{array}$ & $\begin{array}{l}\text { Maturity of Short- } \\
\text { and Lonng-term } \\
\text { Debt (years) }\end{array}$ \\
\hline \multicolumn{6}{|l|}{ External } \\
\hline Pakistan & Jan-99 & Dec-99 & $\begin{array}{c}\text { Strictly } \\
\text { Preemptive }\end{array}$ & 25.7 & 0 and 2.5 \\
\hline $\begin{array}{l}\text { Russia } \\
\text { (PRINs \& IANs) }\end{array}$ & Nov-98 & Aug-00 & Post-Default & 19.2 & -0.1 and 10.9 \\
\hline Ecuador & Jan-99 & Aug-00 & Post-Default & 28.2 & 1.7 and 24.5 \\
\hline Uruguay & Mar-03 & May-03 & $\begin{array}{c}\text { Strictly } \\
\text { Preemptive }\end{array}$ & 8.4 & 0.5 and 24.2 \\
\hline $\begin{array}{l}\text { Argentina } \\
\text { (Global Exchange) }\end{array}$ & Nov-01 & Jun-05 & Post-Default & 13.4 & 0.1 and 22.6 \\
\hline Grenada & Oct-04 & Nov-05 & $\begin{array}{c}\text { Weakly } \\
\text { Preemptive }\end{array}$ & 21.4 & 0 and 13.0 \\
\hline Belize & Aug-06 & Feb-07 & $\begin{array}{c}\text { Weakly } \\
\text { Preemptive }\end{array}$ & 22.4 & 0 and 8.0 \\
\hline Greece & Jul-11 & Mar-12 & Preemptive & 45.4 & 0 and 28.5 \\
\hline $\begin{array}{l}\text { Staint Kitts and } \\
\text { Nevis }\end{array}$ & Jun-11 & Apr-12 & $\begin{array}{c}\text { Weakly } \\
\text { Preemptive }\end{array}$ & 10.3 & 0 and 8 \\
\hline \multicolumn{6}{|l|}{ Domestic } \\
\hline $\begin{array}{l}\text { Russia } \\
\text { (GKOs resident) }\end{array}$ & Aug-98 & May-99 & Post-Default & 2.4 & -0.3 and 0.3 \\
\hline $\begin{array}{l}\text { Argentina } \\
\text { (Phrase I) }\end{array}$ & Oct-01 & Nov-01 & $\begin{array}{c}\text { Strictly } \\
\text { Preemptive }\end{array}$ & 7.8 & 0.5 and 29.6 \\
\hline Uruguay & Mar-03 & May-03 & $\begin{array}{c}\text { Strictly } \\
\text { Preemptive }\end{array}$ & 10.4 & 0.0 and 8.8 \\
\hline Jamaica & Feb-13 & Mar-13 & $\begin{array}{c}\text { Strictly } \\
\text { Preemptive }\end{array}$ & 0.9 & 0 and 33.2 \\
\hline Cyprus & May-13 & Jul-13 & $\begin{array}{c}\text { Strictly } \\
\text { Preemptive }\end{array}$ & 14.7 & 1 and 2.7 \\
\hline
\end{tabular}


Appendix II. Haircuts/Recovery Rates

Figure A1. SZ Recovery and Maturity

(C) Belize 2006-2007 External

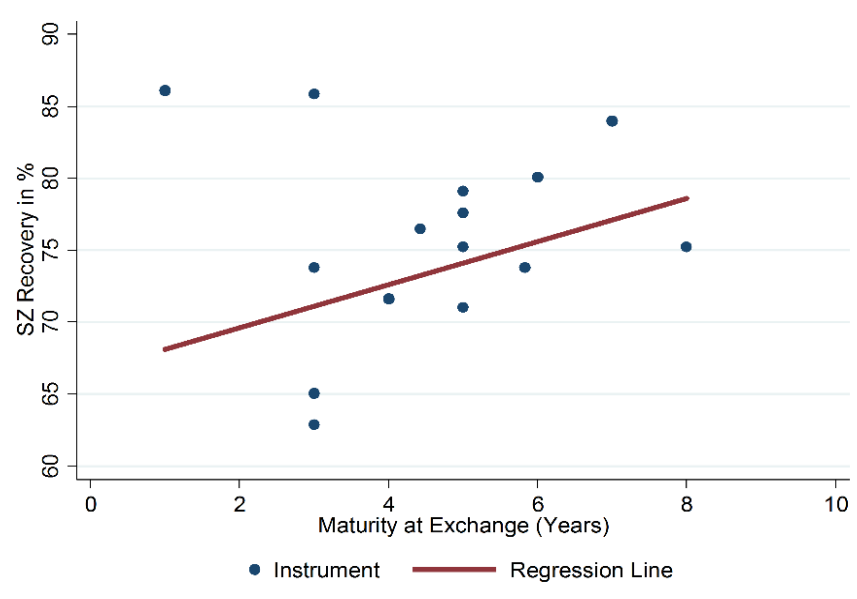

(D) Saint Kitts and Nevis 2011-2012 Domestic

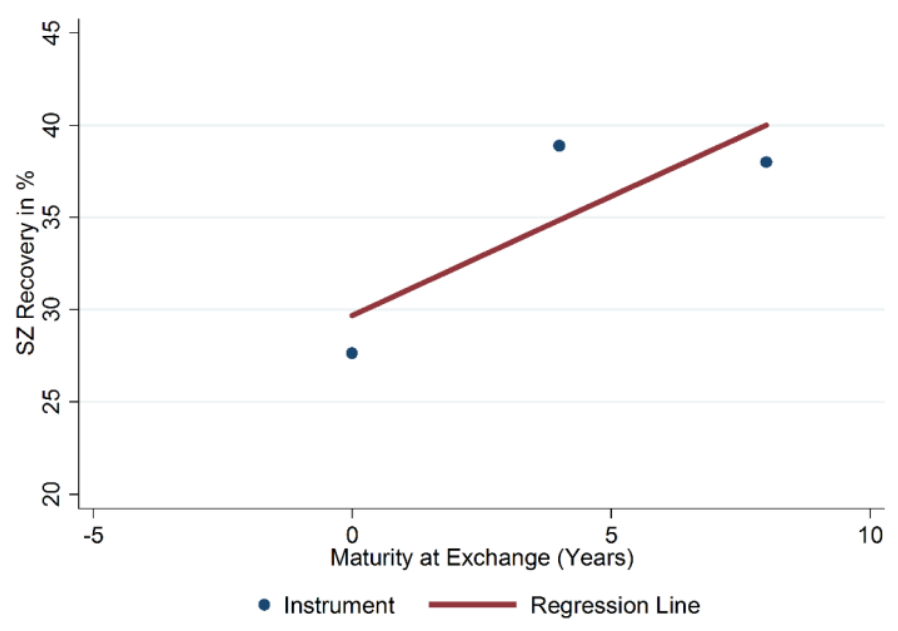


Figure A2. Exchange Recovery and Maturity

(C) Greece 2011-2012 External

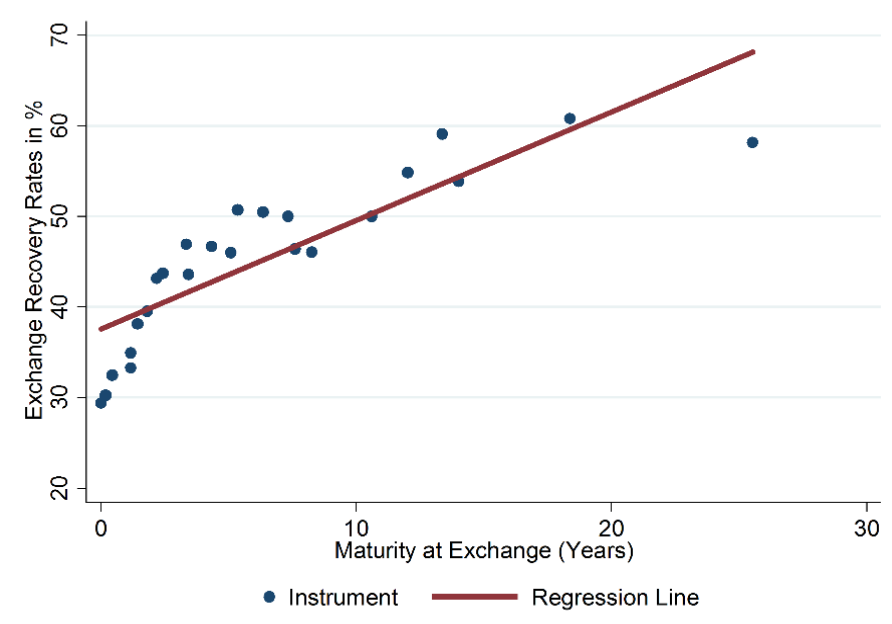

(D) Uruguay 2003 Domestic

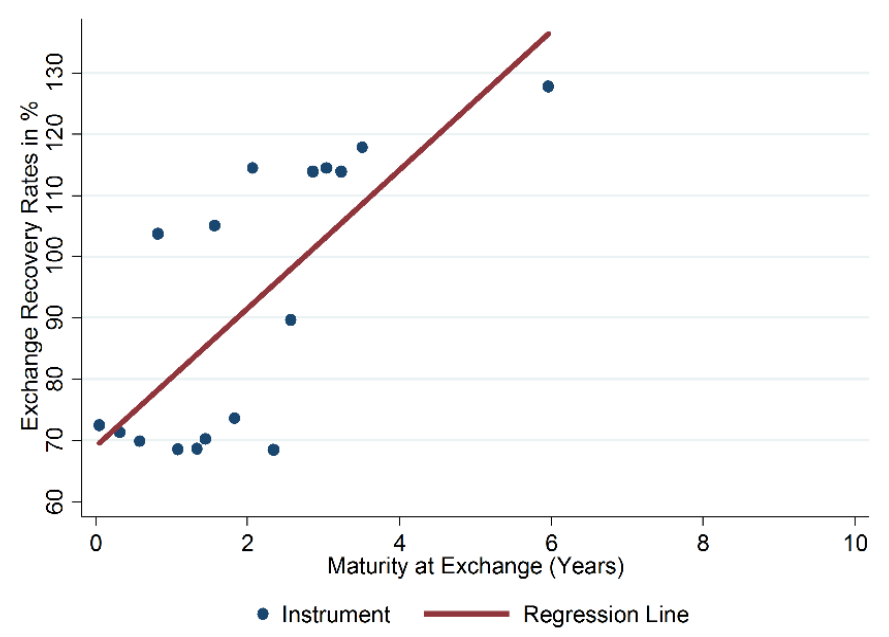


Figure A3. Exchange Recovery and Maturity at Different Points of Time

(A) Pakistan 1999 External - 6 months before the announcement

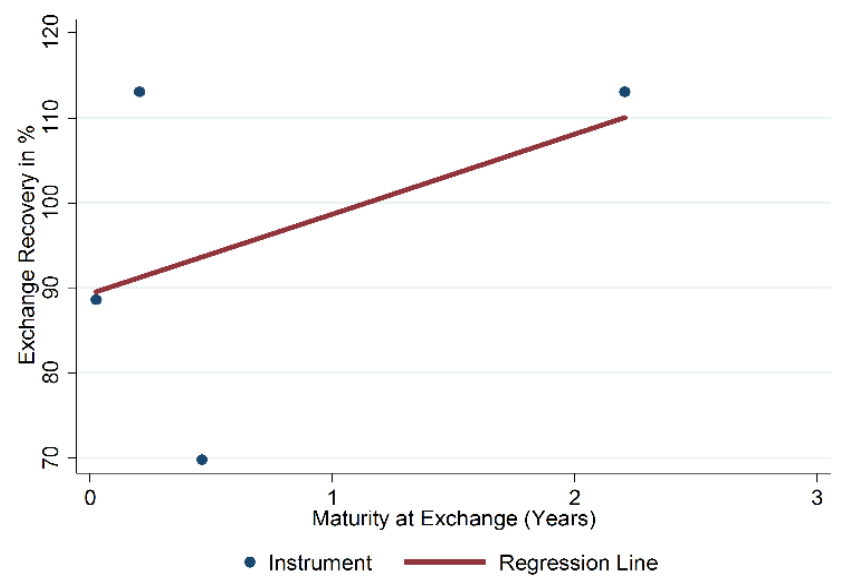

(B) Pakistan 1999 External - 6 months after the announcement

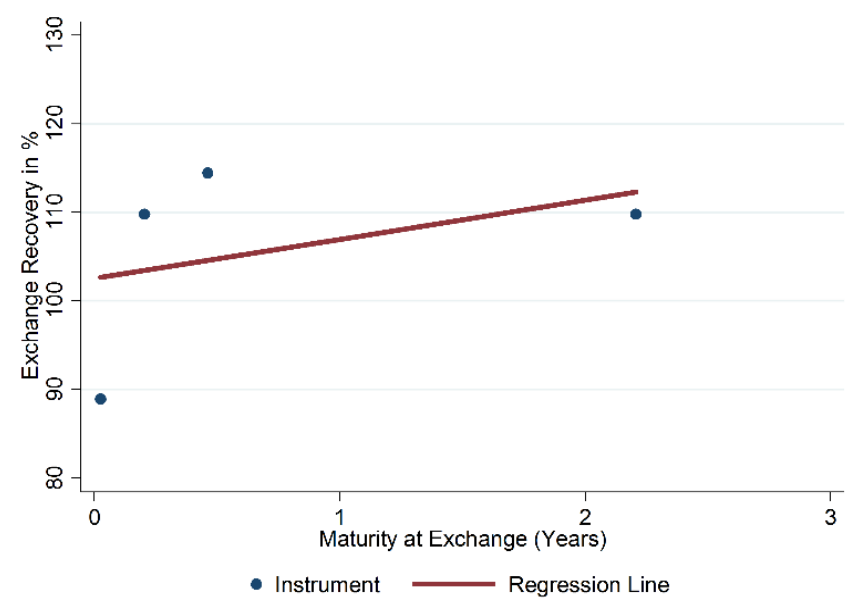

(C) Greece 2011-2012 External - 6 months before the announcement

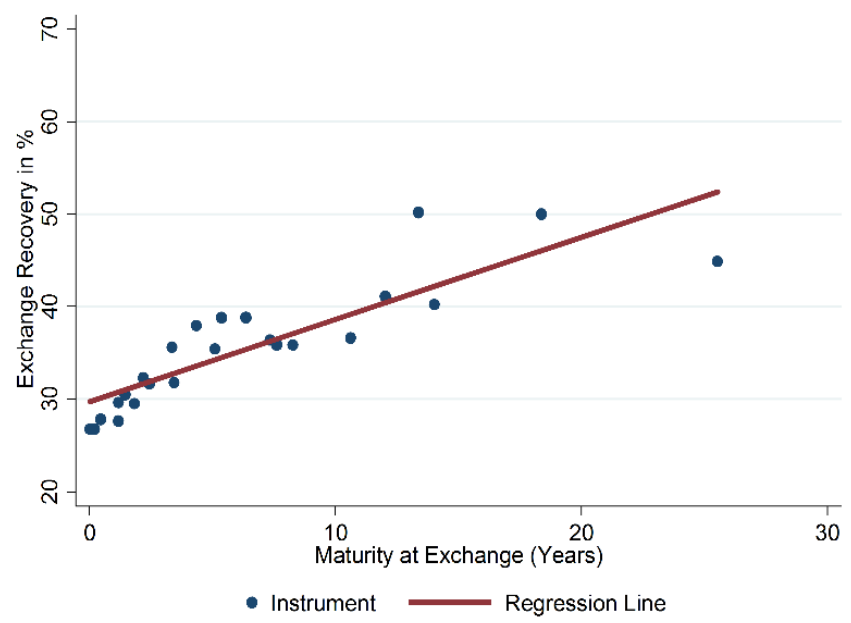

C)International Monetary Fund. Not for Redistribution 
(D) Greece 2011-2012 External - 6 months after the announcement

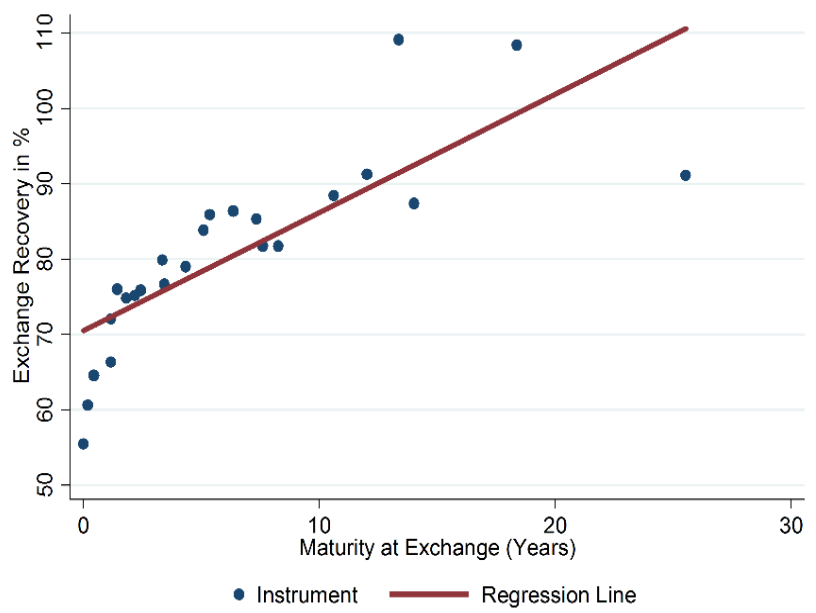

Table A2. Cross-sectional Regression Results

\begin{tabular}{|c|c|c|c|c|}
\hline & $\begin{array}{c}\text { Exchange } \\
\text { Recovery Rate } \\
\text { (6 months before } \\
\text { announcement) }\end{array}$ & $\begin{array}{c}\text { Exchange } \\
\text { Recovery Rate, } \\
\text { with controls }\end{array}$ & $\begin{array}{l}\text { Exchange } \\
\text { Recovery Rate } \\
\text { (6 months after } \\
\text { announcement) }\end{array}$ & $\begin{array}{l}\text { Exchange } \\
\text { Recovery } \\
\text { Rate, with } \\
\text { controls }\end{array}$ \\
\hline & (1) & (2) & (3) & (4) \\
\hline & coef/se & coef $/ \mathrm{se}$ & coef/se & coef/se \\
\hline $\begin{array}{l}\text { Maturity of Instrument } \\
\text { (years) }\end{array}$ & $\begin{array}{l}0.54 * * \\
(0.24)\end{array}$ & $\begin{array}{l}0.54 * * \\
(0.24)\end{array}$ & $\begin{array}{c}5.74 * * * \\
(1.74)\end{array}$ & $\begin{array}{c}5.79^{* * *} \\
(1.81)\end{array}$ \\
\hline $\begin{array}{l}\text { Coupon rate } \\
\text { (fixed, percent) }\end{array}$ & & $\begin{array}{l}-0.76 \\
(0.64)\end{array}$ & & $\begin{array}{c}0.86 \\
(4.95)\end{array}$ \\
\hline $\begin{array}{l}\text { Coupon rate } \\
\text { (float, dummy) }\end{array}$ & & $\begin{array}{l}-11.31 \\
(9.18)\end{array}$ & & $\begin{array}{c}4.53 \\
(74.22)\end{array}$ \\
\hline $\begin{array}{l}\text { Amortization profile (payment } \\
\text { before maturity, dummy) }\end{array}$ & & $\begin{array}{c}-13.61^{*} \\
(7.12)\end{array}$ & & $\begin{array}{c}33.03 \\
(56.42)\end{array}$ \\
\hline $\begin{array}{l}\text { Duration of Restructuring } \\
\text { (years) } \\
\text { External Debt Restructuring } \\
\text { (dummy) }\end{array}$ & & & & \\
\hline Constant & $\begin{array}{c}68.70^{* * *} \\
(1.89)\end{array}$ & $\begin{array}{c}76.68 * * * \\
(5.64)\end{array}$ & $\begin{array}{c}80.04 * * * \\
(15.31)\end{array}$ & $\begin{array}{c}71.25 \\
(42.88)\end{array}$ \\
\hline Episode Fixed Effects & Yes & Yes & Yes & Yes \\
\hline Number of Countries & 12 & 12 & 12 & 12 \\
\hline Number of Restructurings & 16 & 16 & 16 & 16 \\
\hline Observations & 104 & 104 & 111 & 111 \\
\hline Adjusted $R$-Squared & 0.054 & 0.118 & 0.104 & 0.108 \\
\hline
\end{tabular}

The table reports results of fixed effects OLS regressions. The dependent variable is Exchange recovery rate (in $\%)$. The main explantory variable is maturity of instrument at the time of exchange. Columns 1 and 2 report results for Exchange recovery rate 6 months before the announcement and columns 3 and 4 report results for Exchange recovery rate 6 months after the announcement. The control variables are instrument-specific controls and restructuring-specific controls. Significance levels denoted by ${ }^{* * *} \mathrm{p}<0.01,{ }^{* *} \mathrm{p}<0.05,{ }^{*} \mathrm{p}<0.10$. All regressions include restructuring-specific fixed effects. Robust standard errors in parentheses. 


\section{Appendix III. SZ Haircuts Robustness Check}

One advantage of the SZ haircut measure is that it is relatively robust to the posited exit yield of new instruments because both the cash flows of old and new instruments are discounted at the same yield. However, there still remains the question when the exit yield should be measured. To address this concern, we conduct a robustness check and recompute haircuts for higher (exit yield +1 percent) and lower (exit yield -1 percent) yields.

Figure A4 and A5 report results for Dominica 2003-2004 domestic and Belize 2006-2007 external, respectively. In both cases, SZ recovery rates on short-term debt are lower than those on long-term debt whichever yield is used.

Figure A4. SZ Recovery Rate

(A) Dominica 2003-2004 Domestic, exit yield +1 percent

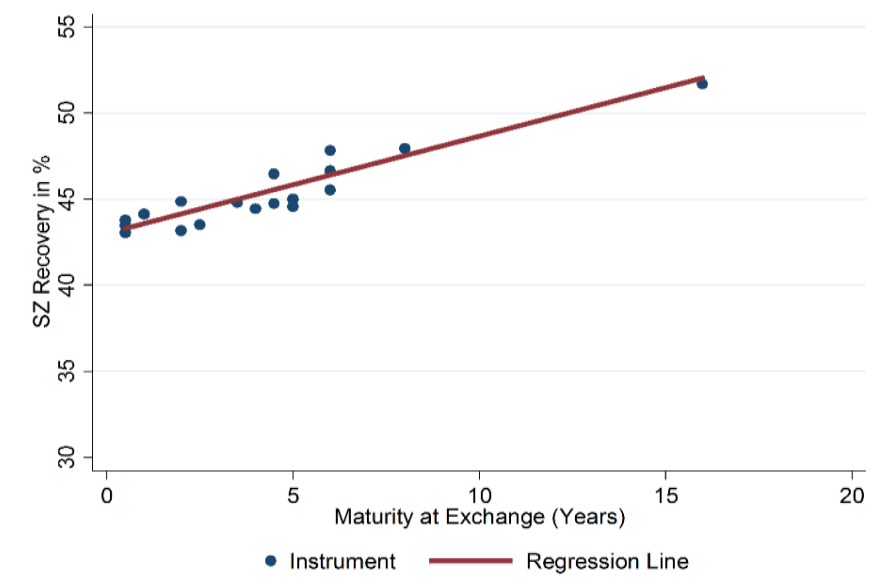

(B) Dominica 2003-2004 Domestic, exit yield -1 percent

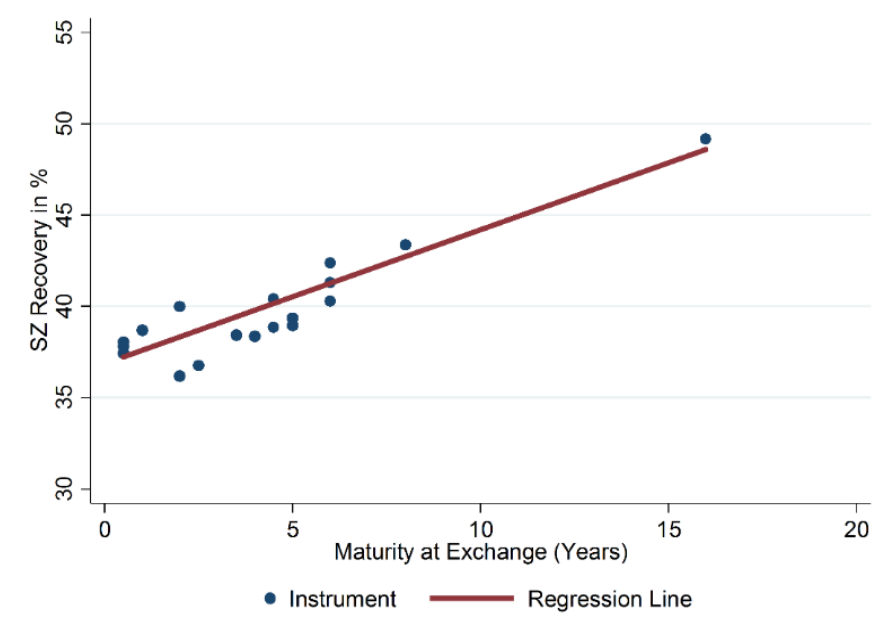


Figure A5. SZ Recovery Rate

(A) Belize 2006-2007 External, exit yield +1 percent

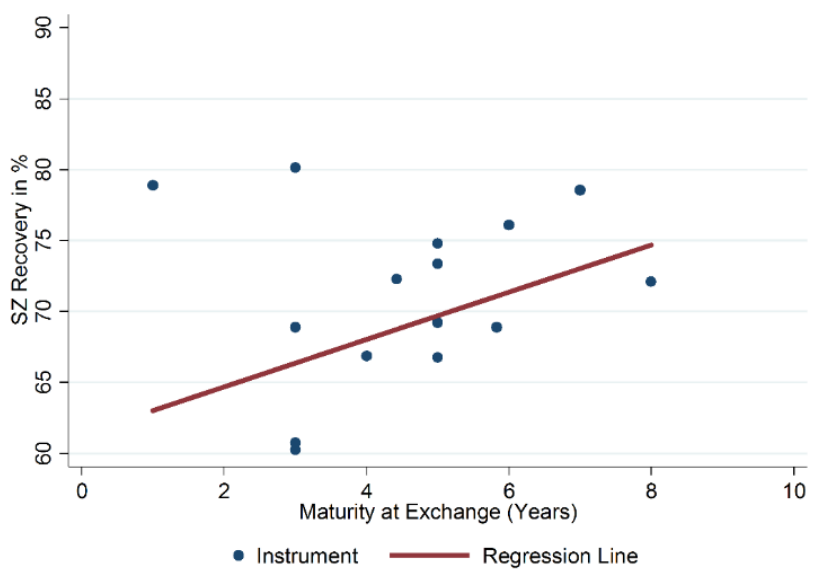

(B) Belize 2006-2007 External, exit yield -1 percent

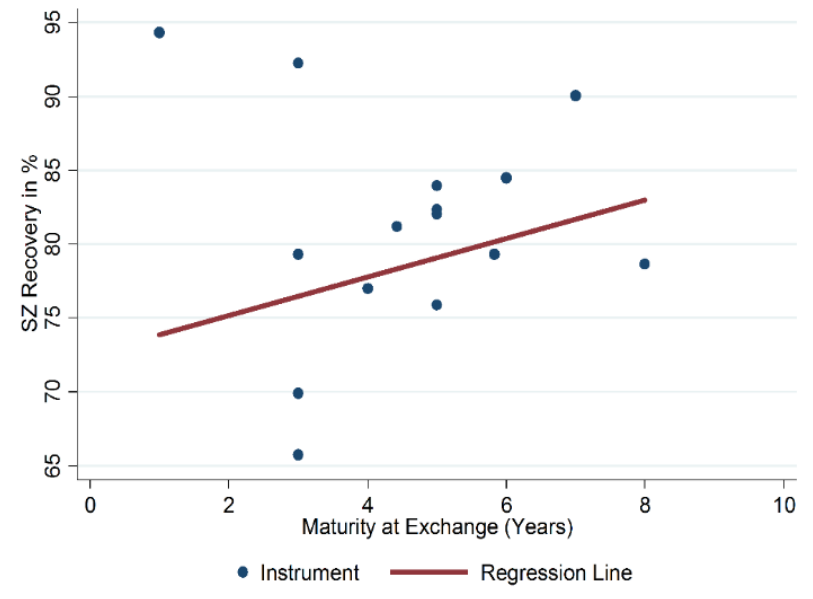




\section{Appendix IV. Bond Prices}

Figure A6. Bond Price Differentials

(C) Dominican Republic 2004-2005 External (bonds)

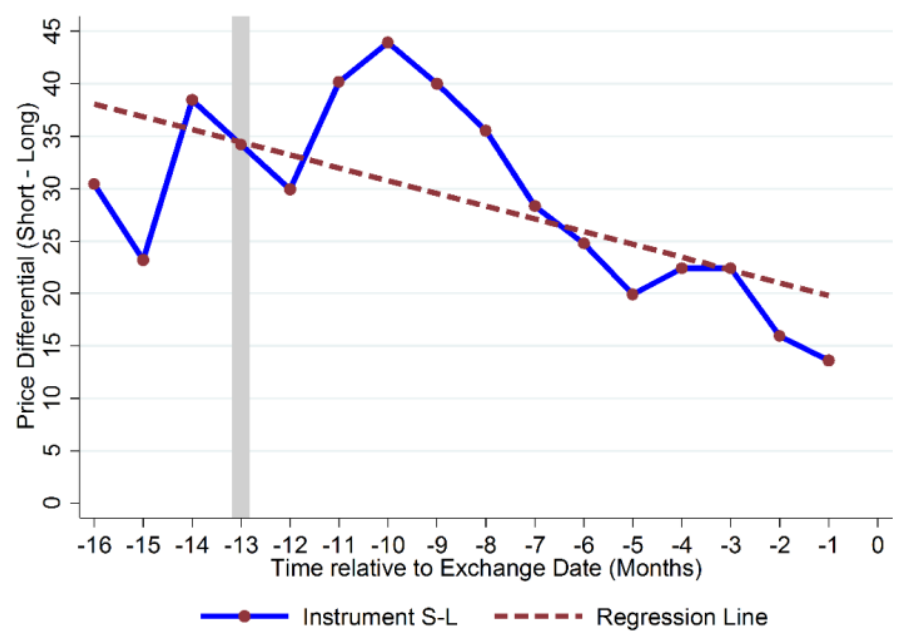

(D) Argentina 2001-2005 External

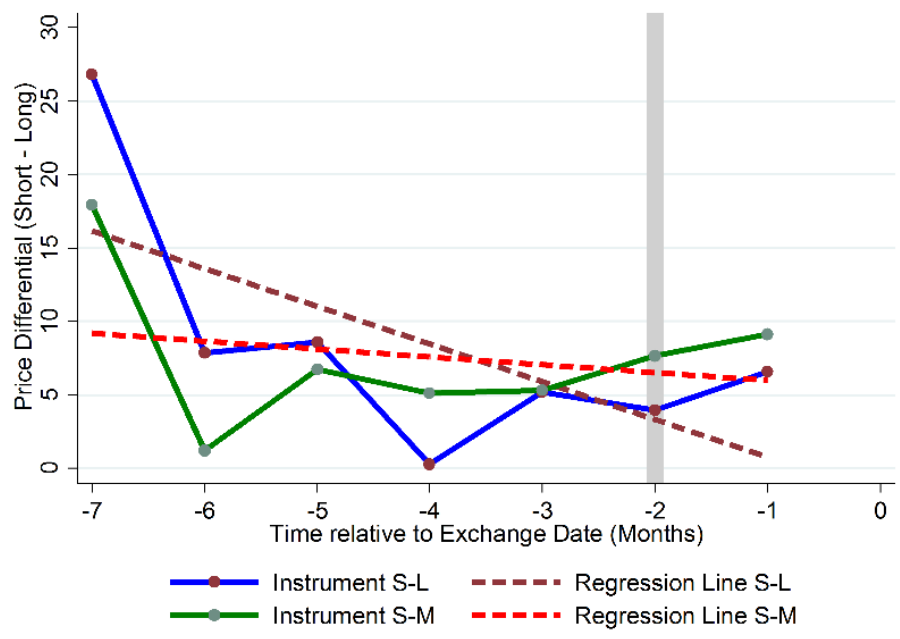

Note: Grey bars indicate the date of the announcement of restructuring. 
Table A3. Panel Regression Results

\begin{tabular}{|c|c|c|c|c|}
\hline & $\begin{array}{l}\text { Bond Price } \\
\text { Differential, } \\
\text { Symmetric }\end{array}$ & $\begin{array}{l}\text { Bond Price } \\
\text { Differential, } \\
\text { Symmetric, } \\
\text { with controls }\end{array}$ & $\begin{array}{c}\text { Bond Price } \\
\text { Differential, } \\
\text { Non-symmetric }\end{array}$ & $\begin{array}{c}\text { Bond Price } \\
\text { Differential, } \\
\text { Non-symmetric } \\
\text { with controls }\end{array}$ \\
\hline & (1) & (2) & (3) & (4) \\
\hline & coef $/ \mathrm{se}$ & coef $/ \mathrm{se}$ & coef $/ \mathrm{se}$ & coef $/ \mathrm{se}$ \\
\hline $\begin{array}{l}\text { Time Span until the Exchange Date } \\
\text { (months) }\end{array}$ & $\begin{array}{c}-1.42^{* * *} \\
(0.09)\end{array}$ & $\begin{array}{c}-1.43^{* * *} \\
(0.10)\end{array}$ & $\begin{array}{c}-1.79 * * * \\
(0.15)\end{array}$ & $\begin{array}{c}-1.81 * * * \\
(0.15)\end{array}$ \\
\hline $\begin{array}{l}\text { Maturity Differential } \\
\text { (S - L, year) }\end{array}$ & $\begin{array}{c}-0.51 * * * \\
(0.05)\end{array}$ & $\begin{array}{c}-0.40 * * * \\
(0.05)\end{array}$ & $\begin{array}{c}0.34 \\
(0.24)\end{array}$ & $\begin{array}{c}0.81 * * * \\
(0.22)\end{array}$ \\
\hline $\begin{array}{l}\text { Duration of Restructuring } \\
\text { (years) }\end{array}$ & & $\begin{array}{c}-37.95^{* * *} \\
(2.41)\end{array}$ & & $\begin{array}{c}-29.37 * * * \\
(4.25)\end{array}$ \\
\hline $\begin{array}{l}\text { Argentina 2001-2005 } \\
\text { Restructuring (dummy) }\end{array}$ & & & & \\
\hline $\begin{array}{l}\text { Strictly Preemptive Restructuring } \\
\text { (dummy) }\end{array}$ & & $\begin{array}{l}-114.63^{* * * *} \\
(7.23)\end{array}$ & & $\begin{array}{l}19.75^{* * *} \\
(2.02)\end{array}$ \\
\hline $\begin{array}{l}\text { Weakly Preemptive Restructuring } \\
\text { (dummy) }\end{array}$ & & & & $\begin{array}{c}-15.74 * * * \\
(5.98)\end{array}$ \\
\hline $\begin{array}{l}\text { External Debt Restructuring } \\
\text { (dummy) }\end{array}$ & & $\begin{array}{c}17.43 * * * \\
(1.56)\end{array}$ & & $\begin{array}{c}48.69^{* * *} \\
(5.11)\end{array}$ \\
\hline Constant & $\begin{array}{r}7.81 * * \\
(3.70)\end{array}$ & $\begin{array}{c}127.09^{* * *} \\
(7.72)\end{array}$ & $\begin{array}{c}1.05 \\
(5.46)\end{array}$ & $\begin{array}{l}-18.02^{* * * *} \\
(2.74)\end{array}$ \\
\hline Episode Fixed Effects & No & No & No & No \\
\hline Number of Restructurings & 6 & 6 & 6 & 6 \\
\hline Number of Pairs of Instruments & 51 & 51 & 15 & 15 \\
\hline Observations & 487 & 487 & 118 & 118 \\
\hline Adjusted $R$-Squared & 0.190 & 0.403 & 0.289 & 0.787 \\
\hline
\end{tabular}

The table reports results of random effects OLS regressions. The dependent variable is bond price differential (price of short-term bond - price of long-term bond). The main explanatory variables are the time span until the exchange date (in months) and maturity differential (maturity of short-term bond - maturity of long-term bond) evaluated at the time of exchange. Columns 1 and 2 report regression results for restructurings with exchanges involving a single menu of new instruments. Columns 3 and 4 report regression results for restructurings with exchanges involving different menus of new instruments. The control variables are episode-specific controls. Significance levels denoted by $* * * \mathrm{p}<0.01,{ }^{* *}$ $\mathrm{p}<0.05, * \mathrm{p}<0.10$. Robust standard errors in parentheses. 


\section{Appendix V. Estimation of Term Structure of Default Risk}

We follow Ranciere (2002).

\section{$1^{\text {st }}$ Step: Constructing the monthly yield curve}

We interpolate the annual yield curve linearly for both (i) CDS spreads and (ii) risk-free interest rates as follows:

$$
\begin{aligned}
& C D S_{t}^{M, j}=C D S_{t}^{A, i}+\frac{j-i}{12}\left(C D S_{t}^{A, i+12}-C D S_{t}^{A, i}\right) \\
& R F_{t}^{M, j}=R F_{t}^{A, i}+\frac{j-i}{12}\left(R F_{t}^{A, i+12}-R F_{t}^{A, i}\right) \\
& \text { for } i=0,12,24,36, \ldots, 108 \text { and } j=i+1, i+2, \ldots i+11
\end{aligned}
$$

The annual yield for 0 -year horizon is assumed to be zero; $C D S_{t}^{A, 0}=R F_{t}^{A, 0}=0$.

where $C D S_{t}^{M, j}$ and $R F_{t}^{M, j}$ denote estimated monthly CDS spreads and risk-free interest rates, respectively. $C D S_{t}^{A, i}$ and $R F_{t}^{A, j}$ denote observed annual CDS spreads and risk-free interest rates, respectively.

\section{$2^{\text {nd }}$ Step: Computing a forward default spread curve}

We apply the no arbitrage condition to derive the forward default spread curve (in month $1,2,3, \ldots, 120)$ as follows:

$$
\begin{aligned}
\left(1+R F_{t}^{M, h, j}+C D S_{t}^{M, h, j}\right)= & \left(1+R F_{t}^{M, j}+C D S_{t}^{M, j}\right) /\left(1+R F_{t}^{M, h}+C D S_{t}^{M, h}\right) \\
& \text { for } j=1,2,3, \ldots, 120 \text { and } h=j-1
\end{aligned}
$$

where $C D S_{t}^{M, h, j}$ and $R F_{t}^{M, h, j}$ denote estimated forward default spreads and forward risk-free interest rates, respectively. The forward default spread measures the implied one-period ahead conditional default risk.

\section{$3^{\text {rd }}$ Step: Computing the term structure of conditional default probabilities}

We use risk-neutrality and the fact that the exchange involves a single menu of new instruments for all restructured instruments to derive the implied one-period ahead conditional default risk:

$$
\begin{gathered}
\left(1+R F_{t}^{M, h, j}\right)=\left(1-\hat{P}_{t}^{h, j}\right) *\left(1+R F_{t}^{M, h, j}+C D S_{t}^{M, h, j}\right)+\hat{P}_{t}^{h, j} * \hat{R}_{t} \\
\text { subject to } \hat{R}_{t}=\operatorname{argmin} \frac{1}{n} \sum_{i=1}^{n}\left\{p_{t}^{i}-\hat{p}_{t}^{i}\left(\left\{R F_{t}^{M, k, k+1}\right\}_{k=h^{\prime}}^{H-1} P_{t}^{j, h}, \hat{R}_{t}\right)\right\}^{2} \\
\text { for } j=1,2,3, \ldots ., 120 \text { and } h=j-1
\end{gathered}
$$

where $\hat{P}_{t}^{h, j}$ and $\hat{R}_{t}$ are the implied one-period ahead conditional default probability and timevariant recovery. The implied time-variant recovery is estimated to minimize mean squared 
deviations of the estimated bond prices $\hat{p}_{t}^{i}\left(\left\{R F_{t}^{M, k, k+1}\right\}_{k=h}^{H-1}, P_{t}^{j, h}, \hat{R}_{t}\right)$-based on inputs of streams of risk-free interest rates until maturity, estimated conditional default risk and timevariant recovery-from the observed price $p_{t}^{i}$. This implied time-variant recovery converges to the observed nominal recovery at the time of exchange as reported in Figure A7. ${ }^{16}$

Figure A7. Implied Nominal Recovery Rate

(A) Ecuador 1999-2000 External

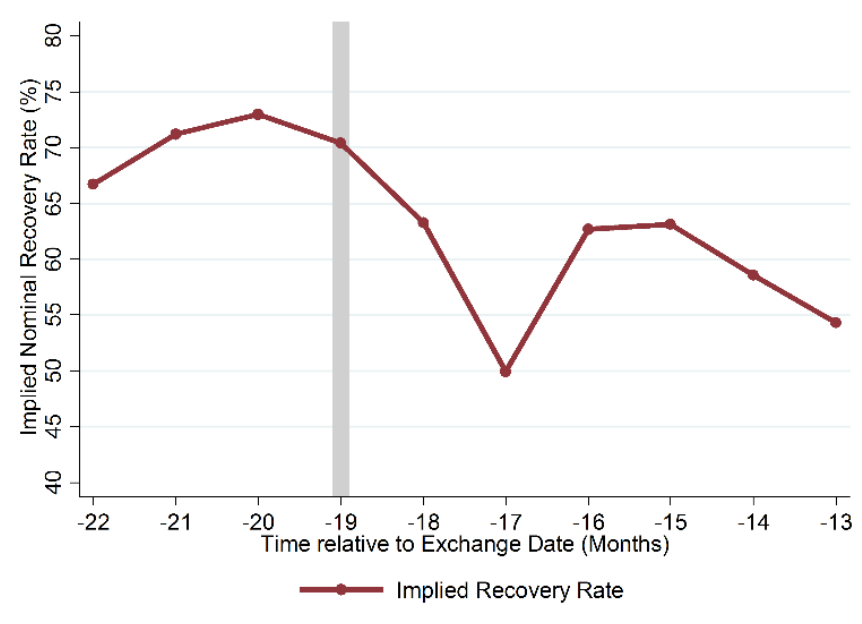

(B) Greece 2011-2012 External

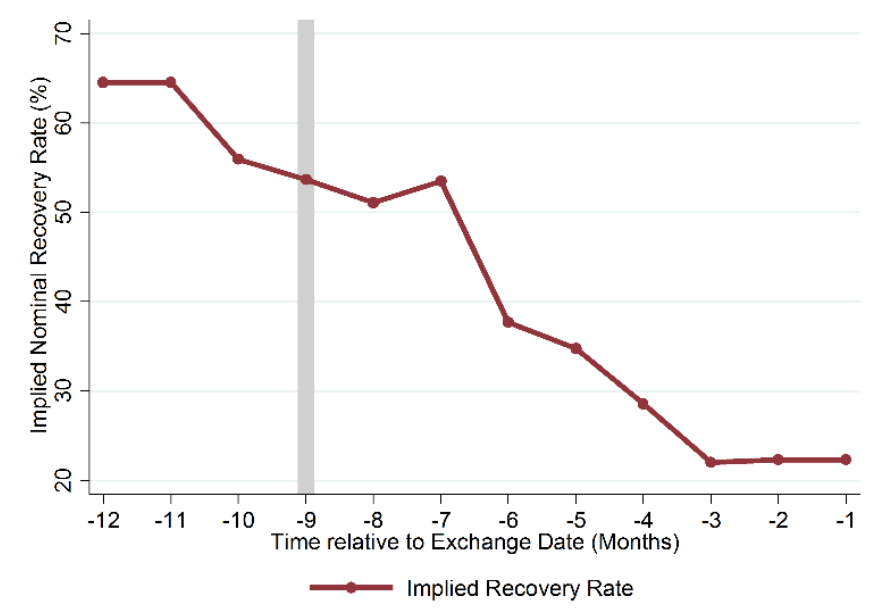

Note: Grey bars indicate the date of the announcement of restructuring.

${ }^{16}$ JP Morgan (2000) proposes an alternative approach to compute implied recovery rates. 


\section{Appendix VI. Default Probability Term Structure}

\section{Figure A8. Default Probability Term Structure}

(A) Argentina 2001-2005 External

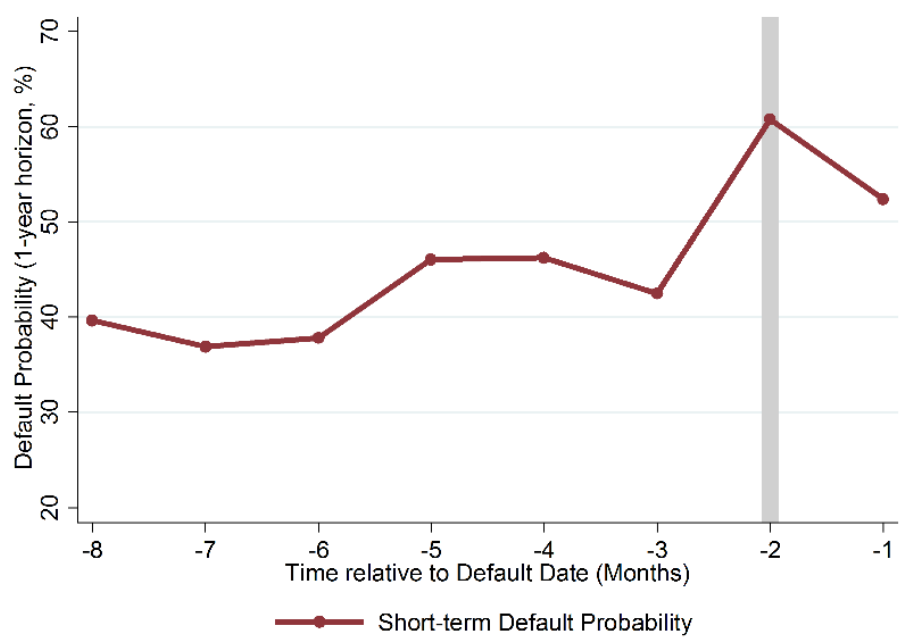

Table A4. Panel Regression Results

\begin{tabular}{|c|c|c|c|c|}
\hline & $\begin{array}{c}\text { Default } \\
\text { Probability } \\
\text { 2-Year } \\
\text { Horizon (\%) } \\
\end{array}$ & $\begin{array}{c}\text { Default } \\
\text { Probability } \\
\text { 2-Year Horizon } \\
\text { with controls }\end{array}$ & $\begin{array}{c}\text { Default } \\
\text { Probability } \\
\text { 3-Year } \\
\text { Horizon (\%) } \\
\end{array}$ & $\begin{array}{c}\text { Default } \\
\text { Probability } \\
\text { 3-Year Horizon } \\
\text { with controls }\end{array}$ \\
\hline & (1) & (2) & (3) & (4) \\
\hline & coef/se & coef/se & coef/se & coef/se \\
\hline $\begin{array}{l}\text { Time Span until the Exchange Date } \\
\text { (months) }\end{array}$ & $\begin{array}{c}0.87 * * * \\
(0.22)\end{array}$ & $\begin{array}{c}2.16^{* * * *} \\
(0.31)\end{array}$ & $\begin{array}{c}0.68^{* * *} \\
(0.21)\end{array}$ & $\begin{array}{c}1.87^{* * *} \\
(0.30)\end{array}$ \\
\hline $\begin{array}{l}\text { Duration of Restructuring } \\
\text { (years) }\end{array}$ & $\begin{array}{l}-1.86 \\
(1.19)\end{array}$ & $\begin{array}{c}-12.01 * * * \\
(2.23)\end{array}$ & $\begin{array}{l}-1.40 \\
(1.14)\end{array}$ & $\begin{array}{c}-10.72 * * * \\
(2.19)\end{array}$ \\
\hline $\begin{array}{l}\text { Strictly Preemptive Restructuring } \\
\text { (dummy) }\end{array}$ & & $\begin{array}{c}-30.69^{* * *} \\
(6.17)\end{array}$ & & $\begin{array}{c}-28.20 * * * \\
(6.06)\end{array}$ \\
\hline Constant & $\begin{array}{l}52.56^{* * * *} \\
(3.83)\end{array}$ & $\begin{array}{l}96.28 * * * \\
(9.27)\end{array}$ & $\begin{array}{l}48.28 * * * \\
(3.65)\end{array}$ & $\begin{array}{l}88.45 * * * \\
(9.09)\end{array}$ \\
\hline Episode Fixed Effects & No & No & No & No \\
\hline Number of Restructurings & 3 & 3 & 3 & 3 \\
\hline Number of Time Periods (months) & 12 & 12 & 12 & 12 \\
\hline Observations & 36 & 36 & 36 & 36 \\
\hline Adjusted $R$-Squared & 0.336 & 0.606 & 0.252 & 0.543 \\
\hline
\end{tabular}

The table reports results from random effects OLS regressions. The dependent variable is the conditional default probability at the 2-year and 3-year horizon (\%). The main explanatory variable is the time span until the exchange date (in months). Columns 1 and 2 report regression results for the default probability at the 2-year horizon and columns 3 and 4 report regression results for the default probability at the 3 -year horizon. The control variables are episode-specific controls. Significance levels denoted by $* * * \mathrm{p}<0.01$, ** $\mathrm{p}<0.05, * \mathrm{p}<0.10$. Robust standard errors in parentheses. 


\section{References}

Aguiar, M., and M. Amador, 2014, "Take the Short Route: How to Repay and Restructure Sovereign Debt with Multiple Maturities," manuscript, Princeton University and Federal Reserve Bank of Minneapolis.

Arellano, C., and A. Ramanarayanan, 2012, "Default and the Maturity Structure in Sovereign Bonds," Journal of Political Economy, Vol.120(2), pp. 187-232.

Asonuma, T., and M. G. Papaioannou, 2016, "Domestic Sovereign Debt Restructurings: Processes, Outcomes and Challenges," Manuscript, IMF.

Asonuma, T., and C. Trebesch, 2016, "Sovereign Debt Restructurings: Preemptive or Postdefault," Journal of European Economic Association, Vol.14(1), pp.175-214.

Bedford, P., A. Penalver, and C. Salmon. 2005. "Resolving Sovereign Debt Crises: The Market-based Approach and the Role of the IMF." Bank of England Financial Stability Review Vol.18(2), pp.91-100.

Benjamin, D., and M.L. Wright. 2009, "Recovery Before Redemption: A Theory of Sovereign Debt Renegotiation.” Manuscript, UCLA.

Broner, F.A., G. Lorenzoni, and S.L. Schmukler, 2013, "Why Do Emerging Economies Borrow Short Term?” Journal of European Economic Association, Vol.11(1), pp.67100 .

Chatterjee, S., and B. Eyigungor. 2012, "Maturity, Indebtedness and Default Risk," American Economic Review, Vol.102(6), pp.2674-2699.

Cline, W.R. 1995. International Debt Reexamined. Washington, DC: Institute for International Economics.

Cruces, J., and C. Trebesch, 2013, "Sovereign Defaults: The Price of Haircuts," American Economic Journal: Macroeconomics, Vol.5(3), pp.85-117.

Diaz-Cassou, J., A. Erce, and J. Vazquez-Zamora, 2008, "Recent Episodes of Sovereign Debt Restructurings. A Case-study Approach,” Banco de Espana Occasional Paper, No. 0804 .

Eaton, J., and M. Gersovitz, 1981, "Debt with Potential Repudiation: Theoretical and Empirical Analysis," Review of Economic Studies, Vol.48(2), pp.289-309.

Eichengreen, B., and R. Portes, 1986, "Debt and Default in the 1930s: Causes and Consequences," European Economic Review, Vol.30(3), pp.599-640.

Eichengreen, B., and R. Portes, 1989, "After the Deluge: Default, Negotiation, and Readjustment during the Interwar Years," In The International Debt Crisis in 
Historical Perspective, edited by B. Eichengreen and P.H. Lindert, 12-47. Cambridge, MA: MIT Press.

Fernandez, R., and A. Martin, 2014, "The Long and the Short of It: Sovereign Debt Crises and Debt Maturity," NBER Working Paper No.20786.

Finger, H., and M. Mecagni. 2007, "Sovereign Debt Restructuring and Debt Sustainability: An Analysis of Recent Cross-Country Experience." International Monetary Fund (IMF) Occasional Paper 255.

Guscina, A., S. Malik, and M.G. Papaioannou, 2017, “Assessing Loss of Market Access,” forthcoming IMF Working Paper.

Hatchondo, J.C., and L. Martinez, 2009, "Long Duration Bonds and Sovereign Defaults," Journal of International Economics, Vol.79(1), pp.117-125.

Hatchondo, J.C., L. Martinez, and C. Sosa-Padilla, 2014, "Voluntary Sovereign Debt Exchanges," Journal of Monetary Economics, Vol.61(S), pp.32-50.

Hatchondo, J.C., L. Martinez, and C. Sosa-Padilla, 2015 "Debt Dilution and Sovereign Default Risk." forthcoming in Journal of Political Economy.

Institute of International Finance (IIF), 2012, "Report of the Joint Committee on Strengthening the Framework for Sovereign Debt Crisis Prevention and Resolution," IIF Principles for Stable Capital Flows and Fair Debt Restructuring \& Addendum, October 2012.

Institute of International Finance (IIF), 2015, "Report on Implementation by the Principles Consultative Group," Principles for Stable Capital Flows and Fair Debt Restructuring, October 2015.

International Monetary Fund (IMF), 2014, "Strengthening the Contractual Framework to Address Collective Action Problems in Sovereign Debt Restructuring," IMF Board Paper, October 2014, available at https://www.imf.org/external/np/pp/eng/2014/090214.pdf.

International Monetary Fund (IMF), 2015, “The Fund's Lending Framework and Sovereign Debt_Further Considerations," IMF Board Paper, April 2015, available at https://www.imf.org/external/np/pp/eng/2014/090214.pdf.

Jeanne, O., 2009, "Debt Maturity and the International Finance Architecture," American Economic Review, Vol.99(5), pp.2135-2148.

JP Morgan, 2000, “Introducing the J.P. Morgan Implied Default Probability Model: A Powerful Tool for Bond Valuation,” September 2000. 
Lindert, P.H., and P.J. Morton, 1989. "How Sovereign Debt Has Worked," In Developing Country Debt and Economic Performance: The International Financial System, Vol.1, edited by Jeffrey Sachs, pp.39-106. Chicago: University of Chicago Press.

Niepelt, D., 2014, "Debt Maturity without Commitment," Journal of Monetary Economics, Vol.68(S), pp.S37-S57.

Ranciere, R., 2002, “Credit Derivatives in Emerging Markets,” manuscript, IMF.

Rieffel, L., 2003, Restructuring Sovereign Debt: The Case for Ad Hoc Machinery, Washington, D.C., Brookings Institution Press.

Rodrik, D., and A. Velasco, 1999, "Short-term Capital Flows," In Annual World Bank Conference on Development Economics, World Bank.

Sturzenegger, F., and J. Zettelmeyer, 2006, Debt Defaults and Lessons from a Decade of Crises, MIT Press.

Sturzenegger, F., and J. Zettelmeyer, 2008, "Haircuts: Estimating Investor Losses in Sovereign Debt Restructurings, 1998-2005," Journal of International Money and Finance, Vol.27(5), pp.780-805.

Zettelmeyer, J., C. Trebesch, and M. Gulati, 2013, "The Greek Debt Restructuring: An Autopsy," Economic Policy, Vol.28(75), pp.513-563. 